\title{
Potential strategies for combating COVID-19
}

\author{
Saba Shamim ${ }^{1} \cdot$ Maryam Khan $^{1} \cdot$ Zelal Jaber Kharaba $^{2} \cdot$ Munazza ljaz $^{1} \cdot$ Ghulam Murtaza $^{3}(\mathbb{C}$
}

Received: 15 April 2020 / Accepted: 18 June 2020 / Published online: 10 August 2020

(c) Springer-Verlag GmbH Austria, part of Springer Nature 2020

\begin{abstract}
Coronavirus disease 2019, also known as COVID-19, is caused by a novel coronavirus named severe acute respiratory syndrome coronavirus 2, or SARS-CoV-2. The infection has now catapulted into a full-blown pandemic across the world, which has affected more than 2 million people and has led to approximately 150,000 fatalities all over the world (WHO). In this review, we elaborate all currently available data that shed light on possible methods for treatment of COVID-19, such as antiviral drugs, corticosteroids, convalescent plasma, and potentially effective vaccines. Additionally, ongoing and discontinued clinical trials that have been carried out for validating probable treatments for COVID-19 are discussed. The review also elaborates the prospective approach and the possible advantages of using convalescent plasma and stem cells for the improvement of clinical symptoms and meeting the demand for an instantaneous cure.
\end{abstract}

$\begin{array}{ll}\text { Abbreviations } \\ \text { ADE } & \text { Antibody-dependent enhancement of infection } \\ \text { CAR T } & \text { Chimeric antigen receptor T cell } \\ \text { CDC } & \text { Center for Disease Control and Prevention } \\ \text { CEPI } & \begin{array}{l}\text { Coalition for Epidemic Preparedness } \\ \text { Innovations }\end{array} \\ \text { CoV } & \text { Coronavirus } \\ \text { CRP } & \text { C-reactive protein } \\ \text { CRS } & \text { Cytokine-release syndrome } \\ \text { EC } & \text { Effective concentration 50 } \\ \text { EMA } & \text { European Medicines Agency } \\ \text { ESR } & \text { Erythrocyte sedimentation rate } \\ \text { FDA } & \text { Food and Drug Administration } \\ \text { HBIG } & \text { Hepatitis B immunoglobulin } \\ \text { HRIG } & \text { Human rabies immunoglobulin } \\ \text { INF } \beta & \text { Interferon beta } \\ \text { rINF } \beta & \text { Recombinant interferon beta } \\ \text { MERS } & \text { Middle East respiratory syndrome }\end{array}$

Handling Editor: Akbar Dastjerdi.

Ghulam Murtaza

gmdogar356@gmail.com

1 Institute of Molecular Biology and Biotechnology, The University of Lahore, Lahore, Pakistan

2 Department of Clinical Sciences, College of Pharmacy, Al-Ain University of Science and Technology, Abu Dhabi, United Arab Emirates

3 Department of Pharmacy, COMSATS University Islamabad, Lahore Campus, Islamabad 54000, Pakistan

\begin{tabular}{|c|c|}
\hline NIAID & $\begin{array}{l}\text { National Institute of Allergy and Infectious } \\
\text { Diseases }\end{array}$ \\
\hline PBPK & $\begin{array}{l}\text { Pharmacology-based pharmacokinetic (PBPK } \\
\text { modeling }\end{array}$ \\
\hline RSV & Respiratory syncytial virus \\
\hline RSV-IG & Respiratory syncytial virus immunoglobulin \\
\hline SARS & Severe acute respiratory syndrome \\
\hline TRALI & Transfusion-related acute lung injury \\
\hline WHO & World Health Organization \\
\hline
\end{tabular}

\section{Introduction to coronaviruses}

Coronaviruses (CoVs) were originally found in chickens, after which they were visualized microscopically for the first time by scientists in the twentieth century [1]. They are round, enveloped RNA viruses with spiked projections on their surface, which gives them the appearance of a crown, hence the name [2]. Usually, these viruses have a zoonotic origin and can cause potentially lethal disease in humans. Bats are the natural reservoir for a wide variety of viruses, with numerous species of bats being hosts to approximately four thousand viruses, including CoVs and deadlier viruses such as Ebola virus [3]. The CoVs transmitted by bats are genetically related to other CoVs such as those causing severe acute respiratory syndrome (SARS) and Middle East respiratory syndrome (MERS), which cause pneumonia and related diseases in humans [4]. The novel CoV, officially termed SARS-CoV-2, and other betacoronaviruses ( $\beta$-CoVs) have been were found to be closely related (more than $90 \%$ sequence identity) to a 
$\mathrm{CoV}$ strain found in bats [5]. It has therefore been suggested that bats were the original reservoir of SARS-CoV-2 and that the virus was transmitted to humans through an intermediate host after accumulating a number of mutations.

CoVs belong to a large family of viruses that are responsible for causing mild to severe respiratory diseases in humans [6]. They contain external spike proteins in their envelope (Fig. 1), which give them a distinguishable appearance and are the source of their name [2]. They are spherical and can vary in diameter from about fifty to two hundred nanometres [3]. The spike glycoprotein (protein $S$ ) is the primary antigenic component of the virus particle. Protein $\mathrm{N}$ is the nucleocapsid protein, which associates with the genomic RNA, and this protein can also be employed as a marker in assays detecting viral antigens.

CoVs are enveloped positive-sense RNA viruses that belonging to the family Coronaviridae [4], which is divided into four genera of viruses depending upon their genomic structure: Alphacoronavirus, Betacoronavirus, Gammacoronavirus, and Deltacoronavirus. Members of the first two of these genera are responsible for disease in humans as well as other animals [2]. Before the advent of SARS-CoV-2, there were six CoVs known to cause infections in humans [1]. $\beta$-CoVs that cause mild to severe respiratory diseases in humans include the novel SARS-CoV-2, which is closely related to to SARS-CoV.

When the world was first being familiarized with SARSCoV-2, almost all of the available knowledge and data about its structure and genotypic and phenotypic characteristics originated from the fervent and extensive research that had been carried out earlier on SARS-CoV and MERS-CoV [3]. "CoV virions are stable" around $\mathrm{pH}$ 7. UV light is known to be effective against $\mathrm{CoVs}$, as are organic solvents such as ether, alcohol (60-95\%), chloroform, and disinfectants with a high concentration of chlorine [8]. Under favorable conditions, infectious virions are capable of persisting on surfaces for periods up to several days.

\section{Diseases caused by coronaviruses in humans}

CoVs are known to cause disease in humans but can be associated with disease in animals as well [8]. New human CoVs arise through zoonosis, with the virus first being transmitted from animals to humans, who infect other humans via close contact. This phenomenon is generally rare, but it is becoming increasingly frequent [2]. For this reason, some $\mathrm{CoVs}$ that are known to infect mammals such as bats can also cause infection in humans, causing mild to severe respiratory ailments. The epidemics of SARS-CoV and MERS-CoV in 2002-2003 and 2012, respectively, were caused by CoVs that caused severe respiratory diseases in humans [3]. SARS-CoV-2, which is the seventh human $\mathrm{CoV}$ discovered to date, originated in the city of Wuhan, China. Diseases in humans that are caused by $\mathrm{CoVs}$ are described in detail below:

Benign CoVs are the second most frequent causative agents of seasonal common colds in humans, the first being rhinoviruses. The frequency of infection tends to increase in the "autumn" and winter, usually causing mild respiratory illness. Typical symptoms of the common cold include sore throat, headache, and cough (wet or dry) among many others, which can be accompanied by fever [2]. Some infections may escalate to serious diseases such as pneumonia, especially in the elderly, in immunocompromised patients, in children, and in those with pre-existing medical conditions.

The SARS and MERS outbreaks, caused by SARS-CoV and MERS-CoV, respectively, caused diseases with similar

Fig. 1 Schematic drawing of a coronavirus [7]

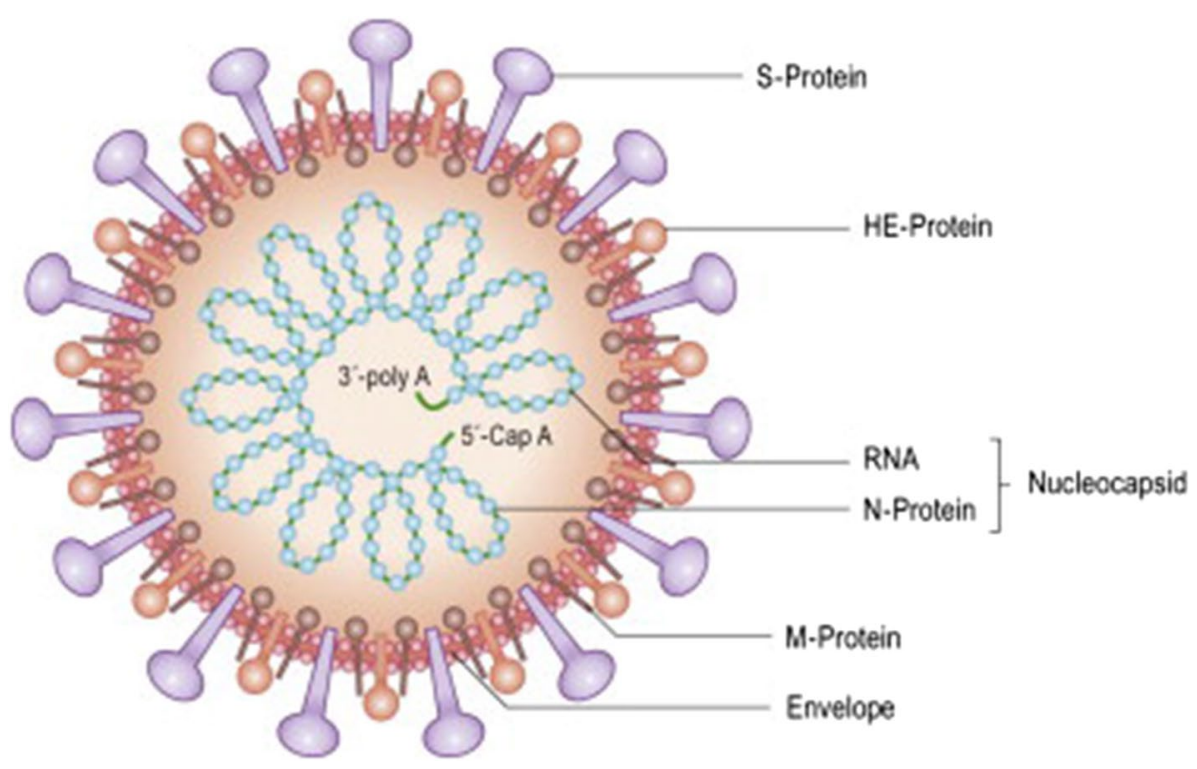


symptoms [8]. These viruses caused acute respiratory infections with the sudden emergence of flu-like symptoms and the aggravation of pre-existing medical conditions [1]. The SARS outbreak severely affected China and neighboring countries, with a fatality rate of about $9 \%$, while the MERS outbreak affected Asia with symptoms similar to those of SARS. However, the fatality rate was far higher for MERS (about 30\%) than SARS.

The coronavirus disease that first occurred in 2019 has been named COVID-19 [9]. The causative agent of this infection is the novel SARS-CoV-2, which tends to replicate in the upper region of the human respiratory system. However, the virus can also enter the lower respiratory tract and can cause lesions despite the patient remaining asymptomatic [5]. The virus has an incubation period of 1-14 in humans, depending on the conditions and the individual.

\section{COVID-19 and its epidemiology}

SARS-CoV-2 is a highly infectious and rapidly spreading $\mathrm{CoV}$ that originated in December 2019 in the city of Wuhan [9]. Soon, epidemic-like conditions were reported in China, where mass gatherings of Chinese people during the Chinese New Year aggravated the situation [3]. Other neighboring countries soon started to report cases, and transmission grew rapidly around the world, eventually affecting countries on all continents except "Antarctica". The characteristics of the infection and transmission are given below:

In the early days of the outbreak, when cases were restricted only to China, the mean incubation period of SARS$\mathrm{CoV}-2$ was reported to be about 5 days [2]. The time on average for its exponential growth (and infection of other individuals) was observed to be about 7 days, while the mean interval for transmission from person to person was also about 7 days. The $R_{0}$ value was found to be between 2 and 8 .

The incubation period varied according to the severity of symptoms. Patients with mild symptoms reported the mean interval to be approximately 5 and 12 days from the beginning of infection to their first treatment and hospital care, respectively, and in patients with severe symptoms, the interval was 7 and 8 days, respectively [1]. The time from the manifestation of the disease to its diagnosis in critically ill patients who eventually died was observed to be considerably longer, with an average of nine days.

The contagion of COVID-19 can be divided into three stages based on current findings and data. This is related to the spread of the virus at a local level, from the food market to humans coming into close contact with the virus. The second stage comprises the communal dissemination of the virus, restricted mainly to dense neighborhoods and families. The third and final stage comprises its worldwide spread, due to mass movements of infected people [6].

\section{Channels of COVID-19 spread}

SARS-CoV-2 infection occurs through the mucosal membrane of the upper respiratory tract [9]. Recent research has suggested two possible modes of transmission. The virus can spread by through direct transmission via respiratory droplets or by indirect transmission via surfaces and materials contaminated with the virus [8]. SARS-CoV-2 has been detected in fecal samples from infected patients, suggesting that it can spread via the fecal-nasal route [3]. The transmission of the virus also occurs in the form of aerosol through the air. However, this mode of transmission only occurs under certain conditions where there is a risk of contamination through samples from infected patients in small and compact spaces.

\section{Demographic features of COVID-19 patients}

The majority of the patients infected with SARS-CoV-2 had either reported a traveling history from the area of origin or inhabited the outbreak area for at least a fortnight before the development of initial symptoms [10]. Patients 60 years of age or more were observed to be critically affected by the disease (30-40\%), with elevated fatality rates (approximately 5-10\%) for patients who had pre-existing medical conditions [5]. Males were found to be infected more frequently (more than 50\%) than the females, with the majority of the infected patients exhibiting benign or conventional symptoms (approximately $80 \%$ ).

\section{Features of COVID-19}

The progression of COVID-19 has been characterized by the typical developmental stages of the disease [10]. The initial stage of infection is usually characterized by fever, although many patients exhibit chills, dry cough, and general fatigue. These symptoms can then advance to labored breathing, with the condition of the patient rapidly deteriorating to respiratory failure in some critical cases [1]. However, in the majority of the cases, the prognosis is good, leading to a complete recovery in patients with milder illness.

Initial screening of the lungs of infected patients tends to reveal pulmonary development and change in the interstices, along with various minute patches [10]. A characteristic feature of respiratory failure known as "white lung" is evident in the most critical cases [6].

A moderate-to-low count of white blood cells is characteristic of the initial stage of the infection [10]. In some studies, an elevation in the levels of hepatic and muscle enzymes and myoglobin has been reported, whereas in other studies, high levels of C-reactive proteins (CRP) and 
erythrocyte sedimentation rate (ESR) have been observed [6]. The amount of D-dimer has been found to be elevated in patients exhibiting severe symptoms [5]. The detection of SARS-CoV-2 can be achieved by rRT-PCR. Furthermore, screening of antibodies in infected individuals at the onset of disease and again after fourteen days can be helpful in ascertaining the pathogenesis of the virus.

\section{Treatment options for COVID-19}

The treatment of mildly infected patients mainly depends upon self-care, and recuperation can occur with routinely used antiviral medicines without any advanced treatment. However, in critically ill patients, the virus wreaks havoc on the immune system of the patients, which demands effective intensive care and a thorough treatment plan [5]. The patients are put under intensive care, and the treatment plan entails electrolyte balancing, administration of water for hydration, and stabilization of the functioning internal systems. All clinical parameters and vital signs should be closely monitored [6]. Routine blood and biochemical parameters should be examined regularly, along with the chest imaging and determination of blood oxygen levels [3]. If oxygen levels are observed to fluctuate, the patient may be given external oxygen. Gas ventilators and nasal oxygen may be helpful for patients suffering from severe respiratory distress. To date, no approved antiviral medicine has been reported. Antibiotics are not generally used for the treatment of the disease. However, patients should be examined for bacterial infections and given antibacterial drugs in cases where there is a risk of bacterial infection [10]. Traditional Chinese medicine (TCM) should be used in combination with conventional medicines after determining the infection symptoms through the conventional method of diagnosis. XueBiJing, Huo Xiang Zheng Qi Shui, Lian Hua Qing Wen Capsule, Shu Feng Jie Du Capsule and Jin Hua Qing Gan Granule have been tested for COVID-19 treatment [11, 12], and these herbal remedies considerably relieved main symptoms, including cough and fever, and were beneficial for the recovery of the patient.

\section{Drug development against COVID-19}

The severity of COVID-19 led to its development of drugs or vaccines [13]. Although the WHO, FDA, and EMA were part of this community, the Chinese took the lead in developing academia-industry partnerships for the development of therapeutics such as monoclonal antibodies, vaccines, and drugs [13]. Such an initiative for vaccine development was recently undertaken by the Coalition for Epidemic Preparedness Innovations (CEPI), involving several countries
[14]. In this context, the establishment of a "vaccine bank" by the Canadian Government is commendable [15]. Scientists are also considering a drug formulation against postinfection complications [16]. Scientists have also taken into consideration previously known antiviral drugs for the treatment of post-infection complications [13]. The International Clinical Trials Registry Platform of WHO is dealing with this issue [16]. In a WHO project named "Solidarity Trial", the four most potent existing antiviral drugs were tested against COVID-19 in ten different countries, and the results were reported [16]. The formulation of drugs and vaccines requires time, and regulatory agencies such as the FDA and EMA have to ensure their safety throughout the drug development cycle (Fig. 2) before approval [15]. This process typically requires almost half a decade [17]. The shortest time frame for developing therapeutics is one and a half years, and that for checking their effectiveness is twelve months [17, 18]. Currently, many new anti-COVID-19 drugs are in phase I of testing [13]. Four antiviral drugs, including hydroxychloroquine (or chloroquine), favipiravir, lopinavir, and remdesivir, have entered phase III or IV. Currently, the CDC is recommending remdesivir as an antiCOVID-19 treatment for COVID-19 patients suffering from pneumonia [13].

\section{Rationalization of drug development against COVID-19}

Novel efforts have been made from 2018 to 2020 to intensify the development of antiviral medications and vaccines. These have included collaborations between constitutional/legislative bodies and industries such as the European Innovative Medicines Project [19], the US Critical Path Program to upgrade advancement of drug development [20], and the Breakthrough Therapy consignment to facilitate the development and regulatory analysis of promising candidate drugs [21]. An international diagnostic pipeline tracker has been designed to facilitate the development of sophisticated diagnostic tools for COVID-19 [22]. A program of augmented therapeutics for COVID-19 management was initiated in March, encouraging researchers and health care professionals to recognize, evaluate, and scale-up potential medications or regimens quickly. In March 2020, CEPI invested US \$100 million to finance different research projects in various countries and also invested US $\$ 2$ billion to quickly develop a vaccine. The COVID-19 Clinical Research Coalition (CRC) was designed to organize, explore, and compile results from globally operated clinical trials investigating the most efficacious post-infection treatment regimen [23]. Various antiviral medications that either are already available on the medicinal market for the management of other infections or have been formulated for recent clinical trials were 
Fig. 2 Drug discovery cycle [17]

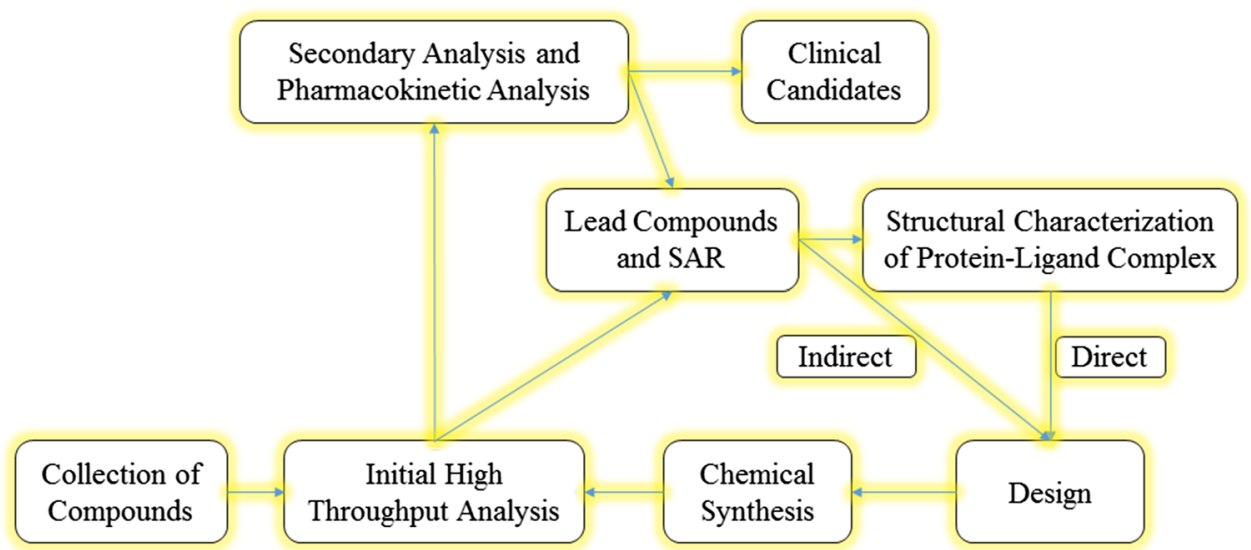

investigated in early 2020 for their potential use against COVID-19 [13, 16, 24-26].

\section{Efforts toward development of a coronavirus vaccine}

Vaccines against numerous CoV-associated diseases have already been developed for use in animals, including those caused by canine coronavirus, feline coronavirus, and contagious bronchitis virus in birds [13]. Previously, attempts were made to develop a vaccine for the management of MERS and SARS caused by viruses of the family Coronaviridae that infect humans [27-29]. The vaccines mentioned above have been tested clinically on research-centered or laboratory-use animal models, and as of 2020 , no vaccine or remedy has been demonstrated to be completely safe and efficacious in humans [30,31]. Globally, the management of SARS using novel therapeutic medications or vaccines is a goal of governmental and public health sector organizations [14]. No approved vaccine against MERS is available $[28,29]$, and the current SARS research was considered a suitable template for the development of medications or vaccines against MERS-CoV illness during the time that it was prevalent [32, 33]. By March 2020, one DNA-based MERS vaccine has been tested in human-based clinical trials (phase I), and three other vaccines were in the development stage. All of these vaccines were viral-vectored, including one MVA-vectored (MVA-MERS-S) vaccine and two adenoviral-vectored vaccines (ChAdOx1-MERS and BVRSGamVac) [34].

COVID-19 emerged in late 2019 and was soon found to be caused by SARS-CoV-2 [13, 25, 35]. In early 2020 , COVID-19 illness became a pandemic, prompting intensive research efforts toward developing vaccines [35, 36]. Several organizations published viral genome sequences to promote the development of safe and efficacious vaccines against SARS-CoV-2 [35-39]. According to the WHO International Clinical Trials Registry Platform, by March 2020, about 100 academic institutions and organizations were actively working worldwide, with 536 clinical trials being conducted [24, 40, 41]. By March 2020, many clinical investigations involving co-administration of multiple antiviral drugs already registered for use against other diseases had been initiated $[24,25]$.

In March 2020, two phase I clinical studies for analysis of safety profiles of vaccines in humans were initiated [37].

A candidate vaccine from Moderna named mRNA-1273 was registered by the National Institute of Allergy and Infectious Diseases (NIAID) in February 2020 to be tested in Seattle, Washington, with studies on human candidates being conducted beginning in March 2020 [42].

A candidate adenovirus vaccine named $\mathrm{Ad} 5-\mathrm{nCoV}$, synthesized by CanSino Biologics Inc. (Tianjin, China) via recombinant technology, was subjected in March 2020 to a phase I safety clinical investigation involving 108 healthy individuals from Wuhan, China, with the study plan running to the end of 2020 [43]. By March 2020, several other candidate vaccines were being quickly optimized and prepared for initial testing in human subjects [13, 24, 40, 41, 44, 45]. Several companies, educational research groups, and global alliances were involved in the initial levels of vaccine preparation, investigations at the laboratory level, or organizing phase I safety clinical trials to further improve candidate vaccines [13, 24, 40, 41]. The government of Canada is contributing a grant of CA $\$ 192$ million for vaccine production and related research studies [46].

\section{Pharmacological agents with prospective clinical advantages}

Several pharmacological agents are being tested against COVID-19 [47-79] and are briefly described below. 


\section{Remdesivir}

Remdesivir (GS-5734) is an adenosine analog drug that was produced for the treatment of the Ebola virus in Africa by Gilead Science and is currently under study. Its mode of action is to bind to the viral RNA polymerase in its active state, where its primary effect is to cause RNA chain termination. It is also reported to exhibit potent antiviral activity against several CoVs, including SARS-CoV-2, with suitable $\mathrm{EC}_{50}$ values. Because it is specific for viral enzymes, it is less likely than some other drugs to be toxic to humans [80-83]. A wide variety of therapeutic index values were obtained for this drug in a human respiratory cell model, according to Sheahan et al. [83]. It is effective against CoVs despite the potential for genetic resistance, and it has a long half-life [84, 85]. For its use against SARS-CoV-2, the tested dosage for treatment was more than $150 \mathrm{mg}$, with intravenous administration on the first day, followed by reduction of the dosage by half for ten days. The antiviral potential of remdesivir was first demonstrated against Ebola virus in monkeys, in which it successfully inhibited the replication of the virus [86]. The antiviral effect of remdesivir has also been investigated in mice, which demonstrated a decrease in the viral load in the lungs, in body weight loss, and in overall lung destruction, which suggested that the drug can inhibit viral replication in the initial stages of infection. However, it was not effective when the viral load was high [82]. The results of that study agreed with those of another study showing the drug to be effective in reducing virus replication and the eventual onset of disease caused by SARSCoV-1 $[82,83]$. It is important to note that while the results of the studies conducted on animal models were encouraging, human clinical trials cast a disappointing shadow on the drug. A human clinical trial demonstrated the fatality rate of patients infected with Ebola virus to be more than $50 \%$ in patients treated with remdesivir and three additional therapies during the Ebola outbreak in 2018, which led to the discontinuation of the drug for the treatment of this disease [87]. The first case of treatment of a patient infected with SARS-CoV-2 with remdesivir was reported in the US, where the drug was administered to the patient a week after typical symptoms of COVID-19 were observed [88]. The drug appeared to ameliorate the patient's condition, although nasopharyngeal swabs continued to be positive for the virus. On the upside, no side effects of the drug were observed in this patient, which corroborated the safety data from cases of treatment of other viral infections with this drug $[89,90]$. Nonetheless, it is important to note that the treatment of three out of twelve COVID-19 patients with remdesivir in the US was carried out under the protocol for compassionate use [91] due to the lack of sufficient data to evaluate its safety or efficacy. At present, there are four ongoing clinical trials in the US that are enlisting patients for potential treatments. Two clinical trials have been commenced in China for the evaluation of remdesivir against COVID-19. The criteria for compassionate use of the drug allow patients in intensive care requiring ventilation support who are too ill to be included in a clinical trial to receive the drug. If they fail to meet these criteria, suffer from organ failure, have renal and hepatic disease, or receive dialysis, they are exempted from compassionate use. These criteria are subject to change, so patients are asked to review the most recent guidelines prior to being enrolled in a clinical trial program. In addition to the time required for approval from the responsible authorities, clinicians also need to be prepared to issue appropriate prescriptions for administering the drug to patients once it is approved. Critically ill patients can be given other antiviral therapies during the waiting time, but these must be suspended immediately once they begin receiving remdesivir. It has been suggested that remdesivir attains its active state by acting as a substrate for CYP-3A4, indicating a possible interaction with related inhibitors such as ritonavir and voriconazole. It has also been suggested that the activity of remdesivir might be enhanced by hydrolase activity, which is also consistent with the chemical structure of the drug. The NIAID was quick to state that it is unlikely that remdesivir would interact with other CYP-3A4 inhibitors [85]. Clinical data have now established remdesivir to be a promising drug for the treatment of patients infected with SARS-CoV-2, and this can be tested further in extensive clinical trials as well as the practical application of the drug in compassionate use, which can provide information about its probable efficacy on a wide scale in the fight against COVID-19.

\section{Chloroquine and hydroxychloroquine}

Chloroquine is an anti-parasitic drug that is used against malaria due to its inflammation-reducing properties and its ability to modulate the immune system. Currently, it has garnered attention because of its potential use in treating COVID-19. The potential antiviral activity of chloroquine against COVID-19 was first reported by Wang et al. [80] during the early outbreak of the novel CoV. The results obtained corroborated previously published results showing antiviral activity of the drug against similar coronaviruses that caused SARS and MERS [92]. The findings of Chinese clinical trials have supported the oral use of the drug at a moderate dosage twice every day, although the rationale for using this dosage remains vague. The use of chloroquine has been associated with stability in patients, with better lung functioning found in scans, leading to a better prognosis and shortened duration of infection, with little or no adverse reactions to the drug, as reported by Gao et al. [63]. The promising results, however, are not sufficient for its 
widespread use, as supply-related problems and cardiovascular toxicity have restricted their use in countries like the USA. As a substitute, another drug called hydroxychloroquine is being investigated. It differs from chloroquine by the presence of an additional hydroxyl group. It is assumed that this drug will be more effective than chloroquine for treating COVID-19, the prolonged use of which has been associated with a rise in rheumatic disorders. The current data regarding the activity of hydroxychloroquine against CoVs are still inadequate. However, in 2006, a comparison of the antiviral potential of these two drugs in cell lines was examined by Biot et al. [93], who demonstrated that chloroquine had superior antiviral activity against SARS-CoV-1 compared to hydroxychloroquine. When these drugs were again studied for their activity against SARS-CoV-2 using a pharmacology-based pharmacokinetic(PBPK) model to examine their activity in respiratory organs, the findings were the opposite of the previous ones, with hydroxychloroquine being more effective than chloroquine against SARS-CoV-2 when the "ratio of the free lung trough concentration to the in vitro $\mathrm{EC}_{50}$ " (RLTEC) values were compared [67]. The reported efficacious dosage of chloroquine was more than $400 \mathrm{mg}$, and therefore, the dosage of hydroxychloroquine was set accordingly in another study [63], which found two dosages that gave a significant effect, first being an oral dose of more than $1000 \mathrm{mg}$ on the first day, followed by less than $500 \mathrm{mg}$ on each of the following days. This dosage resulted in higher RLTEC values for hydroxychloroquine than chloroquine. The second dosage gave similar results, suggesting that a lower dosage of hydroxychloroquine was also effective [67]. However, it is important to note that these drugs have equal half-lives, which would lead to protracted regimens of therapy [94]. It is advised to wait for complete validation and more published data before the administration of the recommended dosage in patients infected with COVID-19. An example can be described to explain the point: If two equally capable compounds were taken and analyzed from the PBPK data for a dosage of hydroxychloroquine less than $1000 \mathrm{mg}$ and varying regimens, RLTEC values would be produced that would be different on consecutive days, which would vary drastically from the dosage of chloroquine taken two times every day with RLTEC values. The majority of clinical trials have used the $400 \mathrm{mg}$ dosage, but the evidence for this remains unclear [67]. Gautret et al. [95] reported the effect of oral administration of $200 \mathrm{mg}$ of hydroxychloroquine after the passage of eight hours in patients infected with COVID-19. The study revealed the drug to be more effective in treating COVID-19 from the nasopharyngeal region. Notably, the use of the antibacterial drug azithromycin, which was given in patients to prevent bacterial infection in COVID-19 cases, resulted in a stronger reduction in the viral load than the use of hydroxychloroquine alone. This finding, although significant, is not sufficient, as various aspects still need be taken into consideration. Clinical data were not adequate, although the reduction in viral load was noteworthy. The study included 26 patients receiving hydroxychloroquine therapy, six of which were excluded from the study for various reasons. Lastly, the patients in the study had a much higher viral titer, as demonstrated by CT values, than other patients who had undergone combined therapy. Although these points indicate that caution is needed in the administration of both chloroquine and hydroxychloroquine, initial studies conducted in China have been hopeful in elucidating the encouraging that both of these drugs might be helpful against COVID-19. It is advised, however, to keep track of the latest study findings by examining works published in peer-reviewed journals until the lack of agreement between studies has been addressed [96]. In the meantime, the administration of hydroxychloroquine needs to be approached with caution.

\section{Lopinavir/ritonavir}

Lopinavir is an HIV protease inhibitor that is administered in combined therapy with ritonavir, which is a potential CYP3A4 inhibitor that enhances the effectiveness of the drug. The reported course of action of lopinavir is the inhibition of the protease enzyme of the virus, thereby blocking its replication [97]. Chu et al. [98] reported the action of various antiviral drugs against SARS-CoV-1 during its outbreak, and the administration of lopinavir and ribavirin was observed to block replication of the virus after just two days of therapy, indicating heightened efficacy when used in combination [98]. The potent activity of lopinavir against SARS-CoV-1 was also reported by de Wilde et al. [99] and was found to be related to the effective plasma concentrations that were examined previously in subjects who had contracted HIV [100]. The potency of lopinavir in combination with ritonavir was compared to that of interferon beta (INF- $\beta$ ) against MERS virus in a study by Sheahan et al. [82], who showed that the administration of these two drugs failed to boost the action of INF- $\beta$ against the virus, where the $\mathrm{EC}_{50}$ values showed the effect of the two drugs to be similar in the case of MERS-CoV and SARS-CoV-1. This study finding was significant, as remdesivir was thought to be the more potent antiviral drug in the same clinical study. Nonetheless, the drug cannot be discounted as being completely ineffective, as an in vivo study found ameliorated clinical and pathogenic symptoms in animals infected with MERS$\mathrm{CoV}$ after combined therapy with lopinavir and ritonavir [101]. At present, a controlled study of combined therapy with both drugs together with rINF- $\beta$ for the treatment of SARS-CoV-2 patients is being conducted in order to rule out any inconsistency between their efficacy in animals and in in vitro studies [102]. This combination was used in 2003 for the treatment of SARS-CoV-1, as mentioned above, in a 
study by Chu et al. [98], in which it was used with ribavirin and corticosteroid drugs. The subjects undergoing lopinavir/ritonavir therapy were compared with subjects receiving ribavirin along with corticosteroids, after which a considerable decrease in the "acute respiratory distress syndrome" (ARDS) and fatality rate was observed. This was further substantiated by another study on more than 70 lopinavir/ritonavir-treated patients who exhibited an overall lower fatality rate than patients who did not receive the two drugs as an initial treatment, which was significant, as advantageous effects of lopinavir/ritonavir were only observed in those patients who received these drugs as an initial treatment [103]. The considerable difference in the fatality rate after treatment against SARS-CoV- 1 and MERS-CoV enabled the testing of lopinavir/ritonavir against SARS-CoV-2 in new clinical trials conducted by scientists in China. Generally, a 400 (and 100)-mg dosage is taken orally twice each day for a maximum of ten days by adults [104]. So far, there are ten clinical trials underway to determine the efficacy of conventional Chinese medicinal therapy and lopinavir/ritonavir, as a singular therapy. Their effect in combination with other antiviral drugs against SARS-CoV-2 is being tested, but the data from this new research are only now coming to light. The administration of lopinavir/ritonavir in positively diagnosed COVID-19 patients in a clinical study resulted in a decrease in auxiliary oxygen in one patient, while the condition of two others worsened. Four out of five patients exhibited severe adverse effects, impeding the execution of the therapy regimen. Other studies have described improvement in the clinical condition of infected patients and an overall reduction in the viral titer after lopinavir/ritonavir treatment. However, the efficacy of this drug therapy remains unclear because of discordant results among studies, variation in the degree of severity of disease in the subjects, and the absence of any standard of treatment [105-108]. Furthermore, the administration of lopinavir/ritonavir along with other antiviral drugs was reported during the early outbreak in Wuhan, but the data and study have not been adequately described with respect to treatment, dosage, and characteristics of the treatment group [109-111]. A recent clinical trial was conducted in which lopinavir/ritonavir combination therapy was compared to twice-a-day and standardized treatment of pneumonia in COVID-19 patients [49]. The initial outcome evaluated was the time until improvement was observed after administration of the therapy. Later, treatment success was evaluated based on fatality rates, time until discharge from the hospital, viral load, and the amount of virus in pharyngeal swabs. The groups did not differ in their time from the initial symptoms to their randomization, and no significant difference was reported for symptom improvement or fatality rate between the two groups. Furthermore, no significant difference was found with respect to the decrease in the viral load. The current data on lopinavir/ritonavir provide little information suggesting their potential for their use in single or combination therapy. The findings that these drugs were effective against SARS-CoV-1 provides some hope, but it should be considered that their activity compared to remdesivir and chloroquine in the case of SARS-CoV-1 was below average, and their inadequate activity in animal models for the treatment of MERS-CoV infection is also not encouraging. It is also noteworthy that, in a randomized trial conducted recently, the time from the start of infection to the commencement of the drug regimen was 13 days in the case of SARS-CoV-2, whereas early treatment proved to be beneficial in the case of SARS-CoV-1. The therapy should include the provision of oral tablets or intravenous solution, which may or may not be given on an empty stomach and should not be administered to patients without screening them for any aggravating symptoms and observing them closely, as some cases do not fulfill the inclusion criteria for COVID-19 clinical trials [112].

\section{Nitazoxanide}

This drug has been investigated for its potency against SARS-CoV-2 in vitro, with acceptable $\mathrm{EC}_{50}$ values [80]. These values are consistent with the values for the drug and its metabolite, known as tizoxanide, obtained in a study with MERS-CoV [113]. Nitazoxanide is a broad-spectrum drug that is reported to be active against various commonly known viruses as well as CoVs due to its antiviral activity, which is assumed to be due to the disruption of the hostmediated pathways that the virus uses for its replication [113]. It is under evaluation for its potency against respiratory viruses. In one study, oral administration $(<500 \mathrm{mg})$ of this drug led to an improvement in clinical features in approximately $24 \mathrm{~h}$ in patients with influenza [114]. This outcome led to investigation in three more phase III clinical trials, which have now been completed, but the study findings are not yet available at this time. However, nitazoxanide treatment did not lead to a decrease in the duration of patients' stay in the hospital or their symptoms in phase II clinical trials [115]. While the use of nitazoxanide against COVID-19 might prove to be efficacious, data from clinical trials are still needed.

\section{Adjunctive pharmacological treatments}

\section{Tocilizumab}

Tocilizumab is a monoclonal antibody that has an inhibitory effect on IL-6, which is released by human macrophages and monocytes during cytokine-release syndrome (CRS). Since its approval by the FDA in 2010, tocilizumab has been used 
as a therapeutic agent in patients with rheumatoid arthritis as a corticosteroid-sparing agent in chimeric antigen receptor T-cell (CAR T therapy) [116]. After seven years, it was approved by the FDA in 2017 to be used as a lifesaving drug for CAR-T-associated CRS. The dose of tocilizumab for CRS depends on its severity [117]. The administration of tocilizumab in arteritis or arthritis patients results in neutropenia or thrombocytopenia, which makes patients more prone to secondary bacterial infections due to release of IL-6. In a case study, adult patients with refractory acute B-cell lymphoblastic leukemia and with grade 3 or higher CRS were found to suffer from secondary bacterial infections. In those patients, it was hard to identify the triggering factor (tocilizumab or corticosteroid) for these bacterial infections [118]. However, no side effects of tocilizumab were reported to the FDA regarding CRS treatment [119]. During the recent pandemic in China, a common observation was that in COVID-19 patients, elevated levels of IL-6 resulted in a cytokine storm, which was often fatal [111]. A beneficial effect of tocilizumab was observed in 21 patients. Treatment with tocilizumab resulted in a lowering of C-reactive protein, fever, oxygen demand, and lung opacity in tomographic images [120]. Before administering tocilizumab, the patients were treated routinely with methylprednisolone, lopinavir, and standard care. Their IL-6 level was $132.38 \pm 278.54 \mathrm{pg} / \mathrm{mL}$ (normal, $<7 \mathrm{pg} / \mathrm{mL}$ ). Although the patients were not accessed for a long period, no side effects were reported during this short period (3-7 days). Tocilizumab as a therapeutic for patients with COVID-19, especially those with increased IL-6 levels, has become a part of the 7th edition of the National Health Commission of the People's Republic of China COVID-19 Diagnosis and Treatment Guide [104]. The National Health Commission has recommended a standard dose of $400 \mathrm{mg}$ IV once, or $4-8 \mathrm{mg} / \mathrm{kg}$. There is an option to repeat a dose in $12 \mathrm{~h}$ (not to exceed a total dose of $800 \mathrm{mg}$ ). Chinese scientists are working on two trials regarding its side effects, but no trials are currently being done in the United States. In the future, there will be more information about tocilizumab. Its administration, time of dose, IL-6 threshold, etc., are all under study. Moreover, the long-term assessment of the patients being treated with tocilizumab will help in establishing its potential role in combating COVID-19.

\section{Corticosteroids}

The role of corticosteroids in the management of COVID19 is of great interest, as there is a need to study their role in secondary infections and other adverse side effects. They have been administered in cases of MERS-CoV- and SARS$\mathrm{CoV}$-1-related pneumonia as a supplementary therapy, but their exact role is difficult to interpret. Patients who received corticosteroids developed a high fever and required more intensive care. The timing of corticosteroid dosage is directly proportional to the duration of disease. The use of corticosteroids immediately enhances fever and leads to a risk of secondary infections by bacteria, and thus poor outcomes, and for this reason such patients need extra care during their intensive care period. The stage of the disease must be kept in mind when choosing a dosage that will result in a swift response while avoiding side effects. Previously, during the SARS-CoV-1 endemic, corticosteroids were given to the patients. The heterogeneity of observations reported, from no effect [121], to a reduction in the death rate [121, 122], to severe side effects and death [123] of ICU-admitted patients [124], prevents clear conclusions from being drawn. On the other hand, in the case of MERS-CoV, the use of corticosteroids resulted in a reduction in mortality [125]. They were given to patients after antiviral drugs had lowered the titer of virus in their bodies. Similar observations were made in patients suffering from SARS-CoV-2 and ARDS [126]. The exact role of corticosteroids is unclear, confusing and inconsistent. They might have a positive impact, but this is still uncertain [127]. A dosage is recommended in the COVID-19 Diagnosis and Treatment Guide from the National Health Commission of the People's Republic of China, where the authors state, "Based on respiratory distress and chest imaging, may consider glucocorticoid that is equivalent to methylprednisolone $1-2 \mathrm{mg} / \mathrm{kg} / \mathrm{day}$ for 3-5 days or less. Note that large-dose glucocorticoid suppresses the immune system and could delay clearance of SARS-CoV-2." [104]. A recent consensus statement from the Chinese Thoracic Society recommends a lower dose, $\leq 0.5-1 \mathrm{mg} / \mathrm{kg}$ per day methylprednisolone for $\leq 7$ days in select patients, after careful consideration of risks and benefits [127].

\section{Pharmacological treatments in which risks outweigh benefits}

\section{Ribavirin with or without interferon}

Ribavirin was approved in the 1980s for viral hemorrhagic fever, respiratory syncytial virus infection, and hepatitis $\mathrm{C}$, together with interferon. It is a guanosine analogue known for interfering with transcription by inhibiting the synthesis of RNA. The combination of ribavirin with corticosteroids and/or interferon against SARSCoV-1 did not show promising results $[128,129]$. Its dose is decided based on the health status of the patient [130]. It was found to be 100 times less effective than remdesivir against SARS-CoV-2 [80]. It is not considered by WHO to be a potential therapeutic agent against SARS-CoV-2. The innate antiviral response is triggered by interferon $(\alpha, \beta)$ and was investigated in SARS-CoV-2 and MERS-CoV infections. When interferon was used in combination with ribavirin, the mortality rate was not 
improved. Furthermore, the following side effects were observed: neuropsychiatric events, fatal ischemia, hepatotoxicity and cytopenia [131]. Despite these observations, the Chinese guidelines recommend ribavirin $500 \mathrm{mg}$ IV 2-3 times daily in combination with LPV/r or inhaled interferon- $\alpha$ ( 5 million units nebulized twice daily) as one of the "standard treatment" options for COVID-19. Due to limited data and a lack of experimental trials, it is not safe to use ribavirin at the moment for the treatment of COVID-19.

\section{Oseltamivir and baloxavir}

Oseltamivir and baloxavir are both used as anti-influenza agents. Currently, oseltamivir is under investigation for COVID-19 treatment. In Wuhan, it was administered to COVID-19 patients in combination with antibiotics. At that time, the causative agent of the disease was not known, and an attempt was made to treat it as though it were influenza. As stated previously [130], oseltamivir was ineffective against SARS-CoV because coronaviruses do not have neuraminidase and are therefore not affected by neuraminidase inhibitors. The same is true for other neuraminidase inhibitors such as zanamivir and peramivir. Currently, the available data also do not support the use of baloxavir against COVID-19. These drugs can be effective against influenza, but once the patient has recovered from influenza, their administration should be stopped.

\section{Agents under investigation for COVID-19}

Table 1 shows various therapeutic agents that have been used against COVID-19. However, these are not recommended and should be avoided. Moreover, Fig. 3 describes various therapeutic targets of different pharmacological agents against COVID-19 at various levels of infection and disease development.

\section{Nitric oxide therapy against COVID-19}

Nitric oxide gas is a human-friendly gas due to the following features: (i) it improves the oxygen supply to bloodstream and thus blood flow in the lungs, (ii) it prevents clot formation, (iii) it destroys toxins, and (iv) it causes the relaxation of the right side of the heart, which is under direct pressure during cardiac arrest. It also has anti-COVID-19 features that were studied previously during the SARS epidemic in 2002-2003. Critically ill patients can be treated by giving them nitric oxide gas, which not only improves lung function but also helps in maintaining the patient's general health status [132].

\section{Convalescent therapies (plasma from recovered COVID-19 patients)}

The COVID-19 pandemic has shaken up the world and has affected almost every living person on this planet. SARSCoV-2 is a new virus for which no vaccines, antibodies, or drugs are currently available. Although many potential vaccines and drugs are being investigated at a feverish pace globally, no breakthrough has been achieved. The use of serum from recovered patients, collected after their convalescence period, is considered to be a possible choice for the treatment of infected patients.

\section{Passive antibody therapy}

Immunization is broadly divided into two types: active and passive. In active immunization, an immune response is induced that is gradual and is dependent on the individual for its potency. In passive immunization, immunity is achieved by providing the recipient with antibodies against a specific disease and is regarded as a safe means of providing immediate immunity against any disease in healthy humans. Unsurprisingly, its history dates back to the 19th century, when it was often the only method used to treat an infectious disease, before the advent of antibiotics in the 20th century [133, 134]. The presence of virus-inactivating antibodies in the serum of recovered patients has been observed in previous $\mathrm{CoV}$ outbreaks, suggesting that immune serum can be used for treatment of CoV infections [135]. Similarly, passive antibody therapy would work against SARSCoV-2 primarily by neutralizing the virus, but it might also contribute to phagocytosis and cytotoxic mechanisms. Not only may therapeutic antibodies be derived from recuperated patients, but monoclonal antibodies or genetically engineered antibodies can also be used [136]. Currently, antibodies derived from recovered patients are the only option for this type of treatment (Fig. 4), with the numbers of donors increasing as the numbers of survivors increases gradually. Passive immunization in humans is generally associated more frequently with preventative healthcare than with the treatment of a specific disease, when it is used following the manifestation of initial signs and symptoms. It is likely to be most effective in the initial stages of infection when the viral load is lower, allowing neutralization by antibodies to occur efficiently [137]. A different aspect of passive immunization is the ability of the antibodies to alter inflammatory responses, which again can be controlled more easily in the early stages of infection. Previously, passive antibody therapy against pneumococcal pneumonia was observed to be most efficacious when it was delivered immediately after the development of initial symptoms [138, 139]. Antibodies obtained through passive therapy tend to reach the affected 
Table 1 Pharmacological agents being investigated against COVID-19

\begin{tabular}{|c|c|c|c|}
\hline Agent & Pharmacological class & Mode of action & $\begin{array}{l}\text { Country where trials are } \\
\text { registered against COVID- } \\
19\end{array}$ \\
\hline Anakinra & Interleukin-1 receptor antagonist & Suppresses cytokine storming & Not registered yet \\
\hline Umifenovir & Antiviral/used against influenza & Inhibits fusion & China \\
\hline Baricitinib & Treats rheumatoid arthritis & $\begin{array}{l}\text { A Janus kinase family (JAK) enzyme inhibi- } \\
\text { tor }\end{array}$ & Not registered yet \\
\hline Bevacizumab & $\begin{array}{l}\text { Recombinant humanized monoclonal anti- } \\
\text { body/used against cancer }\end{array}$ & $\begin{array}{l}\text { Prevents vascular endothelial growth factor } \\
\text { associated with endothelial receptors Flt-1 } \\
\text { and KDR }\end{array}$ & China \\
\hline Brilacidin & Antibiotic & A host defense peptide mimetic & USA \\
\hline Convalescent plasma & $\begin{array}{l}\text { From patients who have recovered from } \\
\text { viral infections }\end{array}$ & $\begin{array}{l}\text { Via production of antibodies against a } \\
\text { disease agent }\end{array}$ & Not registered yet \\
\hline Darunavir/cobicistat & Anti-retroviral & HIV-1 protease inhibitor & Not registered yet \\
\hline Disulfiram & Thiuram derivative & Blocks alcohol oxidation & Not registered yet \\
\hline Eculizumab & Humanized, monoclonal IgG antibody & $\begin{array}{l}\text { Binds to complement protein } \mathrm{C} 5 \text { and pre- } \\
\text { vents the formation of membrane attack } \\
\text { complex }\end{array}$ & USA \\
\hline Favipiravir & Antiviral/used against Ebola & RNA-dependent RNA polymerase inhibitor & USA \\
\hline Galidesivir (BCX4430) & Antiviral/used against Ebola & Nucleoside RNA polymerase inhibitor & USA \\
\hline Griffithsin & Anti-HIV microbicide & Potent HIV entry inhibitor & Not registered yet \\
\hline Nelfinavir & Anti-retroviral & An HIV-1 protease inhibitor & Not registered yet \\
\hline Niclosamide & Anthelminthic & & Not registered yet \\
\hline REGN3048 & Human monoclonal antibody & Binds to $\mathrm{S}$ protein of MERS-CoV & USA \\
\hline Sarilumab & $\begin{array}{l}\text { Human monoclonal antibody/ used against } \\
\text { rheumatoid arthritis }\end{array}$ & IL-6 receptor antagonist & USA \\
\hline Sofosbuvir & Antiviral & $\begin{array}{l}\text { A nucleotide analog inhibitor of hepatitis } \\
\text { C virus }\end{array}$ & Not registered yet \\
\hline TZLS-501 & Human monoclonal antibody & Anti-IL6R & Not registered yet \\
\hline XueBiJing & Anti-pneumonia & Treats sepsis & China \\
\hline
\end{tabular}

tissues through blood, where they can shield them against subsequent pathogenesis. The period in which this immunity remains viable can vary from weeks to many months, and even years, and is highly dependent on the concentration and composition of the antibodies used.

\section{Historical precedents}

Serum antibodies have long been used in the treatment of many diseases caused by viruses, such as poliomyelitis [140], measles [141, 142], mumps [143], and influenza [144]. A meta-analysis showed that the administration of serum from recovered patients to infected patients during the H1N1 influenza pandemic resulted in reduced mortality rates [145]. Although the efficacy of this type of treatment was observed to be dependent on the viral pathogen, it has been employed in numerous viral outbreaks that claimed the lives of millions of people. Nevertheless, it is noteworthy that antibodies were studied and used at that time before any information was available about virus serotypes and clinical studies were approved. The use of serum antibodies has increased in the wake of recent viral outbreaks. They were employed in the treatment of patients during the H1N1 influenza pandemic, where they led to a decrease in the respiratory distress and fatality rates in critically ill patients [146]. Convalescent serum was also experimented with during the Ebola pandemic in 2013. Its use reduced mortality in infected patients compared to those undergoing routine treatment, as observed in a study conducted in Africa during the Ebola outbreak [147]. Furthermore, evidence from studies conducted during various viral outbreaks worldwide suggests that treatment with sera from convalescent patients can improve survival [148-151]. Although every virus is unique, the information gained from these studies is potentially applicable for combating the COVID-19 pandemic.

\section{Experience with the use of convalescent sera against COVID-19}

Two major epidemics in the last two decades have established CoVs as dangerous pathogens that can disease in humans. The SARS epidemic was subdued with strict 


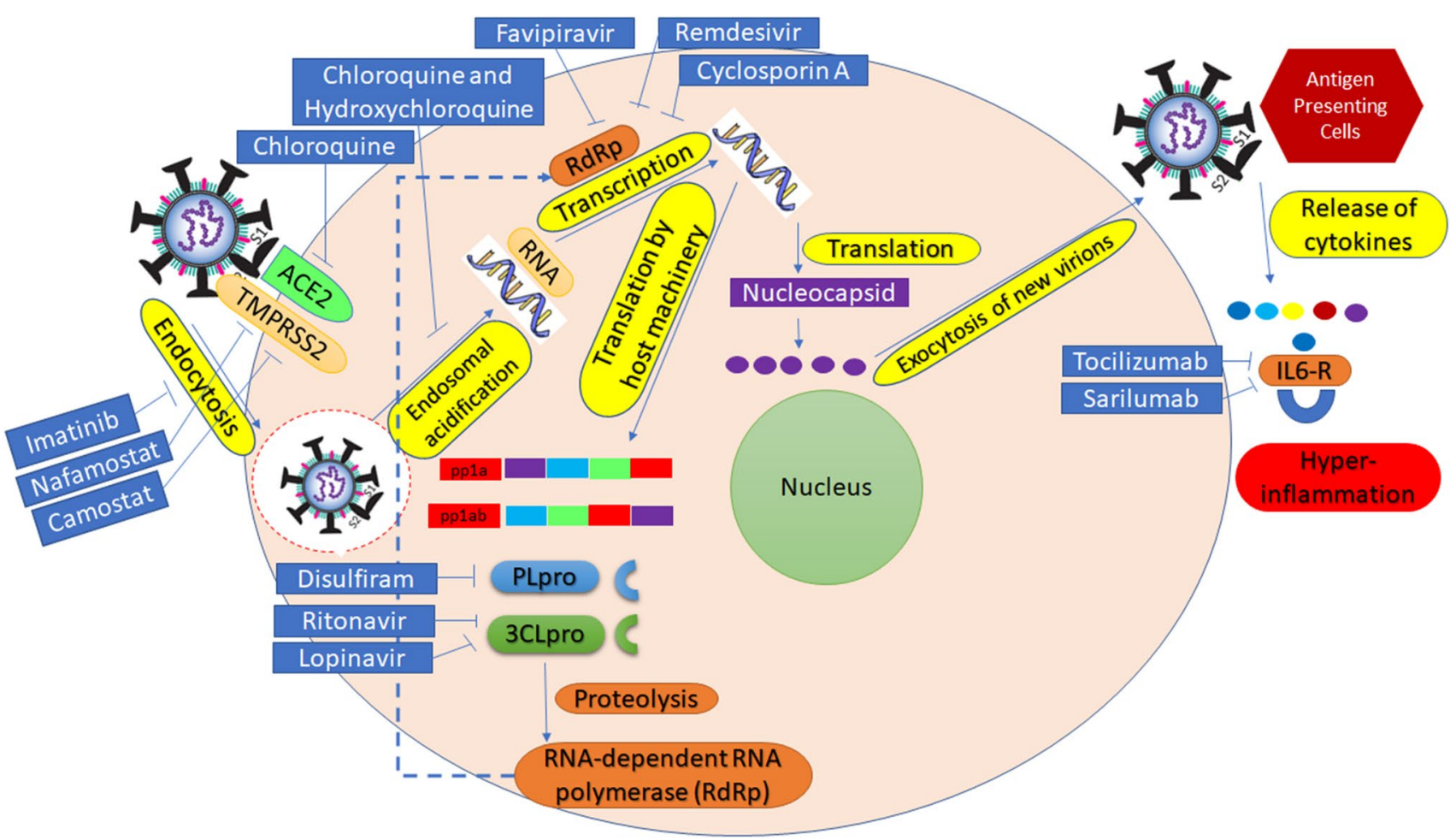

Fig. 3 Therapeutic targets of various pharmacological agents against COVID-19 at various levels of infection and disease progression

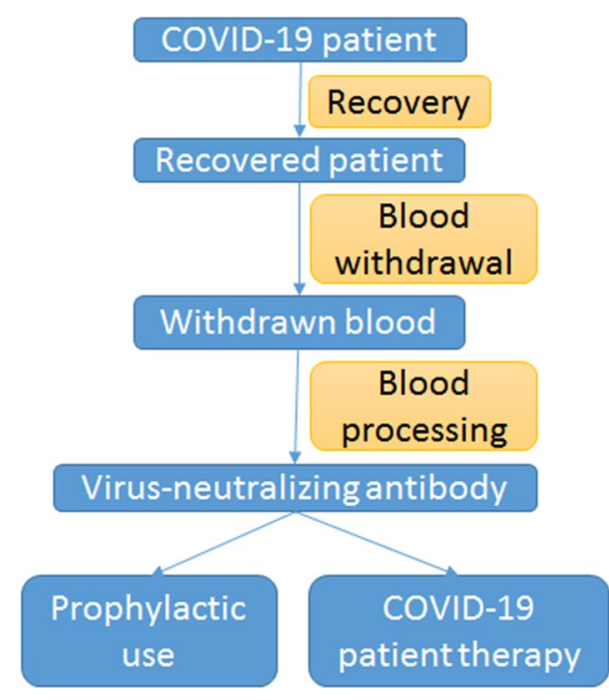

Fig. 4 Use of convalescent sera to treat patients suffering from COVID-19. Blood is drawn from a patient who has recently recovered from COVID-19. This serum contains neutralizing antibodies that can be injected prophylactically to susceptible patients. It is expected that convalescent serum can be used therapeutically for treatment of COVID-19. Although its efficiency as a treatment is still unknown, it is known to prevent the occurrence of disease

management, but the second epidemic of MERS soon spread from the Middle Eastern countries, followed by a second wave of infection in South Korea. In both of these viral outbreaks, high mortality and contagion of disease were observed, which made the spread hard to curb. The lack of approved vaccines and antiviral drugs was also a problem at that time, and infected patients were treated using convalescent sera. This led to many types of research investigating their potential as an effective treatment option. A study conducted in Hong Kong investigated the effect of treatment with convalescent sera on in SARS patients. Upon administration, the individuals treated on day 14 after disease onset, as well as those who tested positive by PCR but were serologically negative for $\mathrm{CoV}$ demonstrated better recovery, which resulted in their subsequent discharge from the hospital in a couple of days, indicating the effectiveness of early treatment [152]. Another study highlighted the decrease in the viral titer, thus enabling the survival of infected patients after they were given about $0.5 \mathrm{~L}$ of serum antibodies from convalesced patients [153]. However, there are limitations to the use of convalescent serum, as some convalescent patients may not produce enough antibodies to inactivate the virus $[154,155]$. This may be due to a decrease in the antibody titer with time or to the fact that not all recovered patients have an elevated titer of neutralizing antibodies in their serum [136]. However, it is known that the production of non-neutralizing antibodies can also contribute to immunity to and recuperation from many viral diseases [156-158]. In the case of SARS-CoV-2, there were several published accounts of the use of convalescent serum 
therapy for the treatment of infected patients in China [159], which shed light on its effectivity and safety for use against COVID-19. Still, more studies can add more weight to the research findings.

\section{Risks and benefits}

Serum antibodies from recovered patients can be effective for treatment of COVID-19 patients, primarily because they offer protection to both already infected patients and those who are at risk of infection. In medical practice, this type of treatment is frequently employed as a precautionary measure. For treatment of HBV and rabies, immunoglobulins (HBIG and HRIG, respectively) are administered to infected individuals, and they are used for treatment of respiratory syncytial virus (RSV) disease in susceptible children. Previously, for both prevention and treatment, a polyclonal immunoglobulin was used that was obtained from donors, but this practice has been replaced by the use of palivizumab, a monoclonal antibody.

Passive antibody therapy using convalescent sera is a pioneering step towards combating several lethal diseases. Still, its potential for large-scale application cannot be evaluated without sufficient scientific evidence from randomized controlled trials. Judging from past studies and the recovery rates achieved using this therapy, it is more likely to be useful for prevention than for rigorous treatment of infection [144]. A major risk of this therapy is the possibility of allergic or immune reactions to the serum. This risk can be minimized through appropriate blood screening practices in which donated blood is screened for infectious agents and reactions with the blood of serum recipients. Nonetheless, the administration of sera in patients with pulmonary disease carries the risk of transfusion-related acute lung injury (TRALI) [160], which should be contemplated in the evaluation and analysis of the risks involved in passive antibody therapy. The other threat that can discourage the use of antibody therapy is antibody-dependent enhancement (ADE) of infection. An escalation of infection can occur due to various antibodies present in the serum, an occurrence that can take place in the case of many viral diseases. This threat is of particular concern in the case of CoVs, where antibodies against one type of $\mathrm{CoV}$ can intensify the resulting infection with another CoV. Still, the intensity of the threat can be estimated in the case of the new $\mathrm{CoV}$, as was the case with MERS [161]. The suggested administration of passive antibodies may work against the virus, as it would involve using high concentrations of neutralizing antibodies, minimizing the threat of ADE. This is supported by historical evidence, as well as by a recent study in which more than 200 patients were administered serum from recuperated COVID-19 patients, indicating its safety [159, 162], but the persistent threat of ADE must be addressed with adequate wariness in clinical trials to prevent any type of intensification of disease. The vulnerability of recovered patients to a secondary infection, enabled by the suppression of the host immune response when antibodies are given to the patients, is an additional theoretical risk of passive therapy. In the case of RSV, treatment with antibodies before administration of the vaccine resulted in the suppression of the humoral immune response [163]. Although effective clinical studies can address this problem, it can also be overcome by vaccinating patients against SARS-CoV-2 later when a vaccine becomes available. Considering the high fatality rate of SARS-CoV-2 in elderly and susceptible patients, the advantages of using this therapy appear to be significantly greater than the risks. Nevertheless, it is imperative to evaluate and estimate all of the risks associated with its use, as was done with recent use of monoclonal antibodies in the treatment of Ebola [87].

\section{Deployment and proposed use}

For administering convalescent serum to COVID-19 patients, standard protocols should be followed. The convalescent serum can be administered if the following conditions are fulfilled: (i) the presence of a proper virology lab to deal with the virus, (ii) approval of the planned research proposal and its details by an institutional review committee, (iii) availability of serum from individuals who recently recovered from COVID-19 disease, (iv) proper serum donation facilities, (v) availability of serological and virological assays for the detection of SARS-CoV-2 in serum and quantification of neutralization activity, (vi) and standard protocols for assessment of any changes in immune response. Administering purified antibodies is preferable to using convalescent serum because of their efficiency and activity. This project is being worked on by a pharmaceutical company, Takeda [164]. The only drawbacks are the amount of time it takes for their preparation and the pre-requisite for blood from recovered COVID-19 patients. The "standard operating procedures" (SOPs) should be defined and followed strictly. It is assumed that the patients who have recuperated successfully from SARS-CoV-2 infection can be safely requested to donate their blood to obtain antibodies. However, these patients must be declared negative for the virus, which can be tested through appropriate screening measures, and the donated blood should also be critically screened for any infectious agents and blood type. It is also imperative to screen every serum sample to determine its antibody titer. Currently, the neutralization titer and required dosage of antibodies are unknown, and this should be a fundamental part of clinical studies focusing on the evaluation of this therapy for treatment of COVID-19. Previous studies have reported the amount of convalescent sera used against measles to be in the range of $0-50 \mathrm{cc}$. In contrast, in the case 
of severe influenza, several hundred milliliters of sera have been used and found to be effective [165]. However, there was no previous backing data on the effective concentration of neutralizing antibodies, indicating that even minute concentrations can aid in the prevention or subsequent treatment of infection. Therefore, prophylaxis against of infection by providing small doses might be efficacious, whereas larger doses may be needed to treat disease, as the viral load at the onset of the disease is much lower than during the peak of the disease. The serum of recuperated patients of COVID-19 can be employed in the treatment of patients displaying onset of disease [166, 167]. Many healthcare staff and paramedics who have been exposed to the virus by treating infected patients have been advised to quarantine or self-isolate, which greatly increases the disease burden on the remaining health care officials. This burden might be lessened by the passive administration of antibodies, which might reduce the length of quarantine and allow medical staff to continue to perform their duties. This can also be extended to the members of the family tending to an infected patient, which can prevent cross-infection and the spread of disease. However, the distribution of convalescent sera, even at a regional level, requires close cooperation between officials at the administrative and medical level, who can safely orchestrate the production and use of this therapy against the COVID-19 pandemic.

\section{Mesenchymal stem cell technology}

Clinicians are aiming to save the lives of COVID-19 patients by controlling the rate of infection and death [168]. Generally, it has been observed that antiviral drugs, even antibiotics, are being recommended, but another aspect is not taken seriously, i.e., the pathogenesis of SARS-CoV-2. Infection causes cytokines (IL-2, IL-6, IL-7, GSCF, IP10, MCP1, MIP1A and TNF $\alpha$ ) to be released, which disturb the exchange of gases in the lungs, leading to acute respiratory distress, cardiac arrest, and secondary infections. According to a recent study, patients shed the virus for 37 days [111]. In hospital patients, age is a major factor in mortality. IL-6 is also another important factor. According to $\mathrm{WHO}$, the fatality rate of COVID-19 is higher than that of influenza (0.1\%), i.e., $0.3 \%$ to $1 \%$. The data show that in a given country, $80 \%$ of infected individuals are asymptomatic, $14 \%$ are severely ill, and $6 \%$ are in critical condition.

\section{Mesenchymal stem cells}

Chinese researchers have observed that stem cell treatment can reverse the symptoms in critically ill patients $[169,170]$. They concluded that natural mechanisms could be used to treat acute inflammatory pneumonia. For example, in one case, liver fibrosis was treated well with "human umbilical cord mesenchymal stem cells" (hUCMSCs), and the ventilator was removed within four days of the treatment. Not only was the patient feeling well but also the hematology report returned to normal after being in an elevated state. Another study [170] was conducted on seven patients who were treated with "mesenchymal stem cells" (MSCs). They returned to normal life within a week. MSC treatment decreased the level of inflammatory cytokines while increasing IL-10. The clinicians studied the behavior of MSC during the treatment of COVID-19 disease. The portal of entry of SARS-CoV-2 is via ACE2 receptors of human cells (alveolar and capillary endothelium), but. MSCs lack ACE2. Thus, the virus cannot bind to them. MSCs have antiinflammatory and immunomodulatory properties, producing TGF $\beta$, HGF, LIF, VEGF, EGF, BDNF and NGF. Thus the use of MSCs has a promising future in the treatment of COVID-19.

\section{Synthetic stem cells - “LIFNano”}

In the case of pneumonia caused by viruses, "leukemia inhibitory factor" (LIF), is a factor that is released by mesenchymal stem cells, protects against damage caused by cytokine production (Fig. 5) [171, 172]. However, the cost of this therapy is high. This can be overcome using nanotechnology, using synthetic stem cells known as "LIFNano", which have a thousand-fold higher efficacy than cell-based LIF [173]. Using a treatment model for "multiple sclerosis" (MS), LIFNano was effective in "experimental autoimmune encephalomyelitis" (EAE) for treating paralysis within $96 \mathrm{~h}$ (Fig. 6), which is consistent with the reported advantages of the use of mesenchymal stem cell therapy against COVID19. Earlier studies have shed light on the use of neural stem cells in EAE, demonstrating that the beneficial effects of the treatment were due to the LIF produced by neural stem cells. Emergent substitute therapies like LIFNano illustrate the promise of using concentrated and safe therapeutic agents that can repair damaged tissues and inhibit the cytokine problem in the case of pneumonia. These treatments can be tested using low-volume trials in which the drug is administered either by inhalation or intravenously.

\section{Conclusions}

COVID-19 management strategies are being worked on globally. Although there are many candidates for antiCOVID-19 therapy, the situation is changing daily. The anti-COVID-19 agent chosen, its dose, and the timing of its application are among the many questions that need to be addressed. The authors are of the opinion that high-risk populations should be given therapy as early as possible 


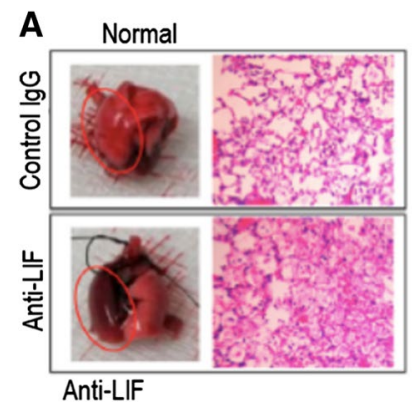

B

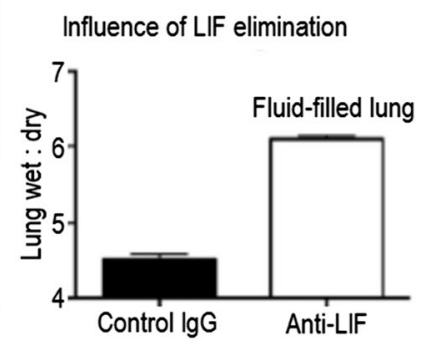

Fig. 5 The effect of LIF on responses against the pathogenesis of infection (adapted from Quinton et al. [172]). Earlier studies highlighted the importance of LIF in the activation of STAT3 and the role of LIF in treatment [175] or its over-regulation [176], which can lead to the inhibition of pulmonary inflammation. This experiment demonstrates the protective role of LIF in the case of lung trauma. Lungs were acquired from experimental mice one day after the introduction of E. coli in the presence of anti-LIF or control IgG. (A) Images of newly isolated lungs with stained lung parts. Red circles indicate infection in the lobes of lungs. (B) Ratios of wet:dry lungs demonstrating the effect of anti-LIF treatment (shown as the mean \pm SEM. $*, p<0.05)$. In the presence of anti-LIF treatment, LIF was not detected, whereas the levels of the remaining cytokines were not significantly changed by this treatment. LIFNanoRx contains nanoparticles of LIF with one-thousand-fold the strength of soluble LIF, and the LIF released slowly over a period of days. LIFNano ${ }^{\circledR}$ is a secondgeneration LIF for the protection of lungs

once it is declared effective and safe. The dose should be adjusted according to the health status of the patient and the progression of the disease. Research scientists and clinicians should keep an eye on new observations published in the literature. Care should be taken when reviewing the literature, as much of the information is not peer-reviewed, selfpublished, or even unpublished. Scientists and clinicians can play an important role in the management of the COVID-19 pandemic as well as modification and optimization of treatment recommendations.

COVID-19 has a low fatality rate, and deaths can be prevented by applying prophylactic measures in the absence of typical treatment. Strict implementation of control regimes is essential to prevent the spread of infection. Medical staff and healthcare personnel should check the travel history of infected patients, along with potential sources of exposure and evident symptoms. Paramedics fighting on the front line against COVID-19 should implement effective and thorough protection initiatives for people vulnerable to viral infection.

Although extensive research is being conducted to develop a suitable vaccine against COVID-19, there is a dire need to shift a major part of the ongoing research towards the treatment of pneumonia in patients, which is often fatal. The astounding data regarding mesenchymal stem cells offers a hopeful approach to the use of an endogenous pathway for the treatment of disease. In the
EAE Model of Multiple Sclerosis
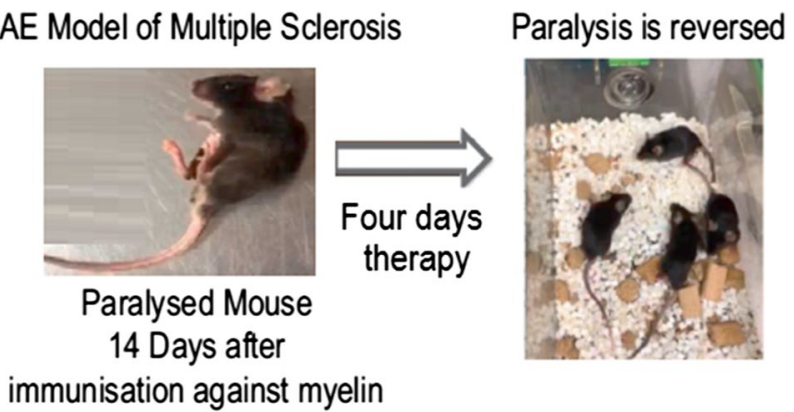

Fig. 6 LIFNano therapy swiftly reverses paralysis in the EAE model (adapted from reference [177]). Mice were immunized against myelin protein, which led to paralysis of the legs and tail region on the fourteenth day of therapy. Hooke's model was used to follow a standardized approach for the experiment. After fifteen days, untreated mice demonstrated persistent paralysis, whereas treated mice demonstrated paralysis for fifteen days after they were treated for $96 \mathrm{~h}$ with LIFNano NPs, which resulted in rapid recovery from paralysis and restoration of mobility with reproducible results (study findings part of a project (I-UK BMC) entitled "Cell-free regenerative medicine: Nano-Engineered "LIFNano" to treat Multiple Sclerosis" Project number: 102847). Fast recovery of motor function is associated with the kinetics of myelin restoration. LIFNano-CD4 penetrates the blood-brain barrier. In this study, mice retained their immune competence

case of pneumonia caused by COVID-19, the balance between the antiviral response and the regulation of LIF action against a cytokine storm may be lost, which can reduce the overall beneficial effect of therapy. Nevertheless, the study findings indicating the safe and effective use of mesenchymal stem cell therapy in treating COVID-19 are indeed remarkable and present a modern approach to the efficient and safe treatment of critically ill patients. For its widespread application, "stem cell" companies are working hand in hand [174], and LIFNano is also on the verge of "current good manufacturing practice" (cGMP) production on a large scale [173].

\section{References}

1. Fan Y, Zhao K, Shi Z-L, Zhou P (2019) Bat coronaviruses in China. Viruses 11(3):210

2. McIntosh K (1974) Coronaviruses: a comparative review. Springer, Berlin, Heidelberg, pp 85-129

3. King AMQ, Adams MJ, Carstens EB, Lefkowitz EJ (2012) Virus taxonomy: classification and nomenclature of viruses. Ninth report of the International Committee on Taxonomy of Viruses. Academic Press, London, Waltham

4. Lau EH, Hsiung CA, Cowling BJ, Chen C-H, Ho L-M, Tsang T, Chang C-W, Donnelly CA, Leung GM (2010) A comparative epidemiologic analysis of SARS in Hong Kong, Beijing and Taiwan. BMC Infect Dis 10(1):50 
5. Sexton NR, Smith EC, Blanc H, Vignuzzi M, Peersen OB, Denison MR (2016) Homology-based identification of a mutation in the coronavirus RNA-dependent RNA polymerase that confers resistance to multiple mutagens. J Virol 90(16):7415-7428

6. Hui DS, Azhar EI, Madani TA, Ntoumi F, Kock R, Dar O, Ippolito G, Mchugh TD, Memish ZA, Drosten C (2020) The continuing 2019-nCoV epidemic threat of novel coronaviruses to global health-the latest 2019 novel coronavirus outbreak in Wuhan, China. Int J Infect Dis 91:264

7. Korsman SN, van Zyl GU, Loiuse N, Anderson MI, Preiser W (2012) Human coronaviruses, vol 9. Churchill Livingstone

8. Namendys-Silva SA (2020) Respiratory support for patients with COVID-19 infection. Lancet Respir Med 8(4):e18

9. Wang C, Horby PW, Hayden FG, Gao GF (2020) A novel coronavirus outbreak of global health concern. Lancet 395(10223):470-473

10. Kahn JS, McIntosh K (2005) History and recent advances in coronavirus discovery. Pediatr Infect Dis J 24(11):S223-S227

11. Song Y, Yao C, Yao Y et al. (2019) XueBiJing injection versus placebo for critically ill patients with severe communityacquired pneumonia: a randomized controlled trial. Crit Care Med 47:e735-e743

12. Yang Y, Islam MS, Wang J, Li Y, Chen X (2020) Traditional Chinese medicine in the treatment of patients infected with 2019new coronavirus (SARS-CoV-2): a review and perspective. Int J Biol Sci 16(10):1708-1717. https://doi.org/10.7150/ijbs.45538

13. Dhama K, Sharun K, Tiwari R, Dadar M, Malik YS, Singh KP, Chaicumpa W (2020) COVID-19, an emerging coronavirus infection: advances and prospects in designing and developing vaccines, immunotherapeutics, and therapeutics. Human Vaccines Immunother 2020:1-7

14. Epidemic response group ups coronavirus vaccine funding to $\$ 23.7$ million. https://www.reuters.com/article/us-health-coron avirus-vaccines-cepi/epidemic-response-group-ups-coronaviru s-vaccine-funding-to-23-7-million-idUSKBN20X1PO. Retrieved 21 Mar 2020

15. Canada to spend $\$ 192 \mathrm{M}$ on developing COVID-19 vaccine. https://globalnews.ca/news/6717883/coronavirus-canada-vacci ne-spending/. Retrieved 24 Mar 2020

16. Maguire BJ, Guérin PJ (2020) A living systematic review protocol for COVID-19 clinical trial registrations. Wellcome Open Res 5(60):60

17. The Drug Development Process. https://www.fda.gov/patients/ learn-about-drug-and-device-approvals/drug-development-proce ss. Retrieved 21 Mar 2020

18. Why will a coronavirus vaccine take so long? https://www.bosto nglobe.com/2020/03/19/opinion/why-will-coronavirus-vaccinetake-so-long/. Retrieved 21 Mar 2020

19. About the Innovative Medicines Initiative. https://www.imi.europ a.eu/about-imi. Retrieved 24 Jan 2020

20. Critical Path Initiative. https://www.fda.gov/science-research/ science-and-research-special-topics/critical-path-initiative. Retrieved 24 Jan 2020

21. Breakthrough Therapy. https://www.fda.gov/patients/fast-track -breakthrough-therapy-accelerated-approval-priority-review/ breakthrough-therapy. Retrieved 24 Jan. 2020

22. SARS-CoV-2 Diagnostic Pipeline. https://www.finddx.org/ covid-19/pipeline/. Retrieved 12 Apr 2020

23. Cattani M (2020) Global coalition to accelerate COVID19 clinical research in resource-limited settings. Lancet 395(10233):P1322-P1325. https://doi.org/10.1016/S0140 $-6736(20) 30798-4$

24. COVID-19 treatment and vaccine tracker. https://milkeninstitute .org/sites/default/files/2020-04/Covid19\%2520Tracker\%2520N EW4-3-20-2.pdf. Retrieved 3 Apr 2020
25. Li G, De Clercq E (2020) Therapeutic options for the 2019 novel coronavirus (2019-nCoV). Nature Publishing Group, Berlin

26. First up for COVID-19: nearly 30 clinical readouts before end of April [https://www.biocentury.com/article/304658/nearly-30trials-for-covid-19-could-start-to-yield-data-in-the-next-coupl e-of-months. Retrieved 10 Apr 2020

27. Severe acute respiratory syndrome (SARS). https://www.cdc.gov/ sars/. Retrieved 10 Apr 2020

28. Prompetchara E, Ketloy C, Palaga T (2020) Immune responses in COVID-19 and potential vaccines: Lessons learned from SARS and MERS epidemic. Asian Pac J Allergy Immunol 38(1):1-9

29. Middle East Respiratory Syndrome (MERS). https://www.cdc. gov/coronavirus/mers/index.html. Retrieved 12 Apr 2020

30. Gao W, Tamin A, Soloff A, D'Aiuto L, Nwanegbo E, Robbins PD, Bellini WJ, Barratt-Boyes S, Gambotto A (2003) Effects of a SARS-associated coronavirus vaccine in monkeys. Lancet 362(9399):1895-1896

31. Kim E, Okada K, Kenniston T, Raj VS, AlHajri MM, Farag EA, AlHajri F, Osterhaus AD, Haagmans BL, Gambotto A (2014) Immunogenicity of an adenoviral-based middle east respiratory syndrome coronavirus vaccine in BALB/c mice. Vaccine 32(45):5975-5982

32. Jiang S, Lu L, Du L (2013) Development of SARS vaccines and therapeutics is still needed. Future Virol 8(1):01

33. SARS (severe acute respiratory syndrome). https://www.nhs.uk/ conditions/sars/. Retrieved 12 Apr 2020

34. Yong CY, Ong HK, Yeap SK, Ho KL, Tan WS (2019) Recent advances in the vaccine development against middle east respiratory syndrome-coronavirus. Front Microbiol 10:1781

35. Fauci AS, Lane HC, Redield RR (2020) Covid-19-navigating the uncharted. N Engl J Med 382:1268-1269. https://doi. org/10.1056/NEJMe2002387

36. Gates B (2020) Responding to Covid-19-a once-in-a-century pandemic? N Engl J Med 382:1677-1679. https://doi. org/10.1056/NEJMp2003762

37. With Wuhan virus genetic code in hand, scientists begin work on a vaccine. https://www.reuters.com/article/us-china-health-vacci nes-idUSKBN1ZN2J8. Retrieved 11 Apr 2020

38. These 21 companies are working on coronavirus treatments or vaccines-here's where things stand. https://www.marketwatc h.com/story/these-nine-companies-are-working-on-coronaviru s-treatments-or-vaccines-heres-where-things-stand-2020-03-06. Retrieved 10 Apr 2020

39. Coronavirus treatment: vaccines/drugs in the pipeline for COVID-19. https://www.clinicaltrialsarena.com/analysis/coron avirus-mers-cov-drugs/. Retrieved 11 Apr 2020

40. Increasing number of biopharma drugs target COVID-19 as virus spreads. https://www.bioworld.com/articles/433331-increasing -number-of-biopharma-drugs-target-covid-19-as-virus-spreads. Retrieved 10 Apr 2020

41. Draft landscape of COVID-19 candidate vaccine. https://www. who.int/blueprint/priority-diseases/key-action/novel-coronaviru s-landscape-ncov.pdf. Retrieved 11 Apr 2020

42. NIH clinical trial of investigational vaccine for COVID-19 begins. https://www.nih.gov/news-events/news-releases/ nih-clinical-trial-investigational-vaccine-covid-19-begins. Retrieved 12 Apr 2020

43. China approves first homegrown COVID-19 vaccine to enter clinical trials. https://www.bioworld.com/articles/43379 1-china-approves-first-homegrown-covid-19-vaccine-to-enter -clinical-trials. Retrieved 12 Apr 2020

44. Coronavirus Drug Update (2020) The latest info on pharmaceutical treatments and vaccines. https://www.forbes.com/sites/ alexknapp/2020/03/13/coronavirus-drug-update-the-latest-infoon-pharmaceutical-treatments-and-vaccines/\#2ea04c8521db. Retrieved 12 Apr 2020 
45. Kupferschmidt K, Cohen J (2020) WHO launches global megatrial of the four most promising coronavirus treatments. Science. https://doi.org/10.1126/science.abb8497

46. Government of Canada funds 49 additional COVID-19 research projects - details of the funded projects. https://www.canada.ca/ en/institutes-health-research/news/2020/03/government-of-canad a-funds-49-additional-covid-19-research-projects-details-of-thefunded-projects.html. Retrieved 12 Apr 2020

47. Information for clinicians on therapeutic options for COVID-19 patients. https://www.cdc.gov/coronavirus/2019-ncov/hcp/thera peutic-options.html. Updated April 7 2020, Retrieved 12 Apr 2020

48. Mitjà $\mathrm{O}$, Clotet $\mathrm{B}(2020)$ Use of antiviral drugs to reduce COVID-19 transmission. Lancet Global Health 8(5):E639-E640. https://doi.org/10.1016/S2214-109X(20)30114-5

49. Cao B, Wang Y, Wen D, Liu W, Wang J, Fan G, Ruan L, Song B, Cai Y, Wei M (2020) A trial of lopinavir-ritonavir in adults hospitalized with severe Covid-19. New Engl J Med 382:1787-1799

50. Harrison C (2020) Coronavirus puts drug repurposing on the fast track. Nat Biotechnol 38(4):379-381

51. Kruse RL (2020) Therapeutic strategies in an outbreak scenario to treat the novel coronavirus originating in Wuhan, China. F1000Res 9:72

52. UN health chief announces global 'solidarity trial' to jumpstart search for COVID-19 treatment. https://news.un.org/en/story /2020/03/1059722. Retrieved 12 Apr 2020

53. Kupferschmidt K, Cohen J (2020) Race to find COVID-19 treatments accelerates. Science 367(6485):1412-1413

54. Cheng MP, Lee TCL, Tan DH, Murthy S (2020) Generating randomized trial evidence to optimize treatment in the COVID-19 pandemic. CMAJ 192(15):E405-E407

55. WHO to launch multinational trial to jumpstart search for coronavirus drugs. https://www.statnews.com/2020/03/18/who-to-launc h-multinational-trial-to-jumpstart-search-for-coronavirus-drugs I. Retrieved 12 Apr 2020

56. WHO Director-General's opening remarks at the media briefing on COVID-19-27 March 2020. https://www.who.int/dg/speec hes/detail/who-director-general-s-opening-remarks-at-the-media -briefing-on-covid-19---27-march-2020. Retrieved 10 Apr 2020

57. Gilead's coronavirus treatment is barreling its way into new clinical trials. https://fortune.com/2020/02/26/gilead-coronaviru s-treatment-clinical-trials-remdesivir/. Retrieved 12 Apr 2020

58. Zhang L, Liu Y (2020) Potential interventions for novel coronavirus in China: a systemic review. J Med Virol 92(5):479-490

59. Coronavirus: Japanese anti-viral drug effective in treating patients, Chinese official says. https://www.independent.co.uk/ news/world/asia/coronavirus-treatment-anti-viral-drug-favipiravi r-avigan-wuhan-china-a9408066.html. Retrieved 10 Apr 2020

60. FDA Approves Phase III Clinical Trial of Tocilizumab for COVID-19 Pneumonia. https://www.cancernetwork.com/news/ fda-approves-phase-iii-clinical-trial-tocilizumab-covid-19pneumonia. Retrieved 11 Apr 2020

61. Request for emergency use authorization for use of chloroquine phosphate or hydroxychloroquine sulfate supplied from the Strategic National Stockpile for Treatment of 2019 Coronavirus Disease. https://www.fda.gov/media/136534/download. Retrieved 12 Apr 2020

62. Cortegiani A, Ingoglia G, Ippolito M, Giarratano A, Einav S (2020) A systematic review on the eicacy and safety of chloroquine for the treatment of COVID-19. J Crit Care 57:279-283

63. Gao J, Tian Z, Yang X (2020) Breakthrough: chloroquine phosphate has shown apparent efficacy in treatment of COVID-19 associated pneumonia in clinical studies. Biosci Trends 14(1):7273 (PubMed PMID: 32074550. In.: Epub 2020/02/20. eng; 2020)
64. Jie Z, He H, Xi H, Zhi Z (2020) Multicenter Collaboration Group of Department of Science and Technology of Guangdong Province and Health Commission of Guangdong Province for Chloroquine in the Treatment of Novel Coronavirus Pneumonia. Expert Consens Chloroquine Phosphate Treat Novel Coronavirus Pneumonia [in Chinese] 2020(10):1001-1939

65. Physicians work out treatment guidelines for coronavirus. https ://www.koreabiomed.com/news/articleView.html?idxno=7428. Retrieved 12 Apr 2020

66. Plaquenil (hydroxychloroquine sulfate) dose, indications, adverse effects, interactions. https://www.pdr.net/drug-summary/Plaqu enil-hydroxychloroquine-sulfate-1911. Retrieved 12 Apr 2020

67. Yao X, Ye F, Zhang M, Cui C, Huang B, Niu P, Liu X, Zhao L, Dong E, Song C (2020) In vitro antiviral activity and projection of optimized dosing design of hydroxychloroquine for the treatment of severe acute respiratory syndrome coronavirus 2 (SARS-CoV-2). Clin Infect Dis 71(15):732-739

68. Van Norman GA (2019) Phase II trials in drug development and adaptive trial design. JACC Basic Transl Sci 4(3):428-437

69. Fogel DB (2018) Factors associated with clinical trials that fail and opportunities for improving the likelihood of success: a review. Contemp Clin Trials Commun 11:156-164

70. Vaccine testing and the approval process. https://www.cdc.gov/ vaccines/basics/test-approve.html. Retrieved 12 Apr 2020

71. Step 2: Preclinical Research. https://www.fda.gov/patients/drugdevelopment-process/step-2-preclinical-research. Retrieved 10 Apr 2020

72. Drug makers are racing to develop immune therapies for Covid-19. Will they be ready in time? https://www.statnews. com/2020/03/19/coronavirus-antibody-therapies-will-they-beready-in-time/. Retrieved 12 Apr 2020

73. Here's Why It's Taking So Long to Develop a Vaccine for the New Coronavirus. https://www.sciencealert.com/who-says-acoronavirus-vaccine-is-18-months-away. Retrieved 12 Apr 2020

74. When will a coronavirus vaccine be ready? https://www.thegu ardian.com/world/2020/apr/06/when-will-coronavirus-vaccinebe-ready. Retrieved 10 Apr 2020

75. Clinical development success rates: 2006-2015. https://www. bio.org/sites/default/files/legacy/bioorg/docs/Clinical\%2520D evelopment $\% 2520$ Success $\% 2520$ Rates\%25202006-2015\%2520\%2520BIO,\%2520Biomedtracker,\%2520Amplion\%25202016. pdf. Retrieved 10 Apr 2020

76. Trial drug can significantly block early stages of COVID-19 in engineered human tissues. https://www.eurekalert.org/pub_relea ses/2020-04/uobc-tdc040220.php. Retrieved 12 Apr 2020

77. Monteil V, Kwon H, Prado P, Hagelkrüys A, Wimmer RA, Stahl $M$ et al (2020) Inhibition of SARS-CoV-2 infections in engineered human tissues using clinical-grade soluble human ACE2. Cell 181(4):905-913.e7

78. Zhang L, Lin D, Sun X, Curth U, Drosten C, Sauerhering L, Becker S, Rox K, Hilgenfeld R (2020) Crystal structure of SAR$\mathrm{SCoV}-2$ main protease provides a basis for design of improved $\alpha$-ketoamide inhibitors. Science 368(6489):409-412

79. Dong L, Hu S, Gao J (2020) Discovering drugs to treat coronavirus disease 2019 (COVID-19). Drug Discov Ther 14(1):58-60

80. Wang M, Cao R, Zhang L, Yang X, Liu J, Xu M, Shi Z, Hu Z, Zhong W, Xiao G (2020) Remdesivir and chloroquine effectively inhibit the recently emerged novel coronavirus (2019-nCoV) in vitro. Cell Res 30(3):269-271

81. Gordon CJ, Tchesnokov EP, Feng JY, Porter DP, Gotte M (2020) The antiviral compound remdesivir potently inhibits RNAdependent RNA polymerase from Middle East respiratory syndrome coronavirus. J Biol Chem AC120:013056

82. Sheahan T, Sims A, Leist S, Schäfer A, Won J, Brown A, Montgomery S, Hogg A, Babusis D, Clarke M (2020) Comparative therapeutic efficacy of remdesivir and combination lopinavir, 
ritonavir, and interferon beta against MERS-CoV. Nat Commun 11:222

83. Sheahan TP, Sims AC, Graham RL, Menachery VD, Gralinski LE, Case JB et al (2017) Broad-spectrum antiviral GS-5734 inhibits both epidemic and zoonotic coronaviruses. Sci Transl Med 9(396):EAAL3653

84. Agostini ML, Andres EL, Sims AC, Graham RL, Sheahan TP, Lu X, Smith EC, Case JB, Feng JY, Jordan R (2018) Coronavirus susceptibility to the antiviral remdesivir (GS-5734) is mediated by the viral polymerase and the proofreading exoribonuclease. MBio 9(2):e00221-e1218

85. Siegel D, Hui HC, Doerffler E, Clarke MO, Chun K, Zhang L et al (2017) Discovery and synthesis of a phosphoramidate prodrug of a pyrrolo [2, 1-f][triazin4-amino] adenine C-nucleoside (GS-5734) for the treatment of ebola and emerging viruses. J Med Chem 60(5):1648-1661

86. Warren TK, Jordan R, Lo MK, Ray AS, Mackman RL, Soloveva V, Siegel D, Perron M, Bannister R, Hui HC (2016) Therapeutic efficacy of the small molecule GS-5734 against Ebola virus in rhesus monkeys. Nature 531(7594):381-385

87. Mulangu S, Dodd LE, Davey RT Jr, Tshiani Mbaya O, Proschan M, Mukadi D, Lusakibanza Manzo M, Nzolo D, Tshomba Oloma A, Ibanda A (2019) A randomized, controlled trial of Ebola virus disease therapeutics. N Engl J Med 381(24):2293-2303

88. Holshue ML, DeBolt C, Lindquist S, Lofy K, Wiesman J, Bruce $\mathrm{H}$ et al (2020) First case of 2019 novel coronavirus in the United States. N Engl J Med 382(10):929-936

89. Jacobs M, Rodger A, Bell DJ, Bhagani S, Cropley I, Filipe A, Gifford RJ, Hopkins S, Hughes J, Jabeen F (2016) Late Ebola virus relapse causing meningoencephalitis: a case report. Lancet 388(10043):498-503

90. Dörnemann J, Burzio C, Ronsse A, Sprecher A, De Clerck H, Van Herp M, Kolié M-C, Yosifiva V, Caluwaerts S, McElroy AK (2017) First newborn baby to receive experimental therapies survives Ebola virus disease. J Infect Dis 215(2):171-174

91. First 12 patients with coronavirus disease 2019 (COVID19) in the United States. https://www.medrxiv.org/conte nt/10.1101/2020.03.09.20032896v1.full.pdf. Retrieved 14 Mar 2020

92. Colson P, Rolain J-M, Lagier J-C, Brouqui P, Raoult D (2020) Chloroquine and hydroxychloroquine as available weapons to fight COVID-19. Int J Antimicrob Agents 55(4):105932

93. Biot C, Daher W, Chavain N, Fandeur T, Khalife J, Dive D, De Clercq E (2006) Design and synthesis of hydroxyferroquine derivatives with antimalarial and antiviral activities. J Med Chem 49(9):2845-2849

94. Tett SE (1993) Clinical pharmacokinetics of slow-acting antirheumatic drugs. Clin Pharmacokinet 25(5):392-407

95. Gautret P, Lagier J-C, Parola P, Meddeb L, Mailhe M, Doudier B et al (2020) Hydroxychloroquine and azithromycin as a treatment of COVID19: results of an open-label non-randomized clinical trial. Int J Antimicrob Agents 56(1):105949

96. Touret F, de Lamballerie X (2020) Of chloroquine and COVID19. Antiviral Res 177:104762

97. Ratia K, Pegan S, Takayama J, Sleeman K, Coughlin M, Baliji S, Chaudhuri R, Fu W, Prabhakar BS, Johnson ME (2008) A noncovalent class of papain-like protease/deubiquitinase inhibitors blocks SARS virus replication. Proc Natl Acad Sci 105(42):16119-16124

98. Chu C, Cheng V, Hung I, Wong M, Chan K, Chan K, Kao R, Poon L, Wong C, Guan Y (2004) Role of lopinavir/ritonavir in the treatment of SARS: initial virological and clinical findings. Thorax 59(3):252-256

99. de Wilde AH, Jochmans D, Posthuma CC, Zevenhoven-Dobbe JC, van Nieuwkoop S, Bestebroer TM, van den Hoogen BG, Neyts J, Snijder EJ (2014) Screening of an FDA-approved compound library identifies four small-molecule inhibitors of Middle East respiratory syndrome coronavirus replication in cell culture. Antimicrob Agents Chemother 58(8):4875-4884

100. Aspiroz EL, Buelga DS, Figueroa SC, Galera RML, Pascuet ER (2011) Hurlé AD-G, Sánchez MJG: Population pharmacokinetics of lopinavir/ritonavir (Kaletra) in HIV-infected patients. Ther Drug Monit 33(5):573-582

101. Chan JF-W, Yao Y, Yeung M-L, Deng W, Bao L, Jia L, Li F, Xiao C, Gao H, Yu P (2015) Treatment with lopinavir/ritonavir or interferon- $\beta 1 \mathrm{~b}$ improves outcome of MERS-CoV infection in a nonhuman primate model of common marmoset. J Infect Dis 212(12):1904-1913

102. Arabi YM, Asiri AY, Assiri AM, Jokhdar HAA, Alothman A, Balkhy HH, AlJohani S, Al Harbi S, Kojan S, Al Jeraisy M (2020) Treatment of Middle East respiratory syndrome with a combination of lopinavir/ritonavir and interferon- $\beta 1 \mathrm{~b}$ (MIRACLE trial): statistical analysis plan for a recursive two-stage group sequential randomized controlled trial. Trials 21(1):1-8

103. Que T, Wong V, Yuen K (2003) Treatment of severe acute respiratory syndrome with lopinavir/ritonavir: a multicentre retrospective matched cohort study. Hong Kong Med J 9(6):399-406

104. The diagnosis and treatment guide of COVID-19 pneumonia caused by new coronavirus infection, 7 th edn. https://www. gov.cn/zhengce/zhengceku/2020-03/04/content_5486705.html. Accessed 6 Mar 2020

105. Young BE, Ong SWX, Kalimuddin S, Low JG, Tan SY, Loh $\mathrm{J}$ et al (2020) Epidemiologic features and clinical course of patients infected with SARSCoV-2 in Singapore. JAMA 323(15):1488-1494

106. Lim J, Jeon S, Shin H-Y, Kim MJ, Seong YM, Lee WJ, Choe K-W, Kang YM, Lee B, Park S-J (2020) Case of the index patient who caused tertiary transmission of COVID-19 infection in Korea: the application of lopinavir/ritonavir for the treatment of COVID-19 infected pneumonia monitored by quantitative RTPCR. J Korean Med Sci 35(6):E79

107. Han W, Quan B, Guo Y, Zhang J, Lu Y, Feng G, Wu Q, Fang F, Cheng L, Jiao N, Li X, Chen Q (2020) The course of clinical diagnosis and treatment of a case infected with coronavirus disease 2019. J Med Virol 92(5):461-463

108. Wang Z, Chen X, Lu Y, Chen F, Zhang W (2020) Clinical characteristics and therapeutic procedure for four cases with 2019 novel coronavirus pneumonia receiving combined Chinese and Western medicine treatment. Biosci Trends 14(1):64-68

109. Wang D, Hu B, Hu C, Zhu F, Liu X, Zhang J, Wang B, Xiang $\mathrm{H}$, Cheng Z, Xiong Y et al (2020) Clinical characteristics of 138 hospitalized patients with 2019 novel coronavirus-infected pneumonia in Wuhan, China. JAMA 323(11):1061-1069

110. Chen N, Zhou M, Dong X, Qu J, Gong F, Han Y, Qiu Y, Wang J, Liu Y, Wei Y (2020) Epidemiological and clinical characteristics of 99 cases of 2019 novel coronavirus pneumonia in Wuhan, China: a descriptive study. Lancet 395(10223):507-513

111. Zhou F, Yu T, Du R, Fan G, Liu Y, Liu Z et al (2020) Clinical course and risk factors for mortality of adult inpatients with COVID-19 in Wuhan, China: a retrospective cohort study. Lancet 395(10229): 1054-1062

112. Best BM, Capparelli EV, Diep H, Rossi SS, Farrell MJ, Williams E, Lee G, van den Anker JN, Rakhmanina N (2011) Pharmacokinetics of lopinavir/ritonavir crushed versus whole tablets in children. J Acquir Immune Defic Syndr 58(4):385

113. Rossignol J-F (2016) Nitazoxanide, a new drug candidate for the treatment of Middle East respiratory syndrome coronavirus. J Infect Public Health 9(3):227-230

114. Haffizulla J, Hartman A, Hoppers M, Resnick H, Samudrala S, Ginocchio C, Bardin M, Rossignol J (2014) Effect of nitazoxanide in adults and adolescents with acute uncomplicated 
influenza: a double-blind, randomised, placebo-controlled, phase 2b/3 trial. Lancet Infect Dis 14(7):609-618

115. Gamiño-Arroyo AE, Guerrero ML, McCarthy S, RamírezVenegas A, Llamosas-Gallardo B, Galindo-Fraga A, MorenoEspinosa S, Roldán-Aragón Y, Araujo-Meléndez J, Hunsberger S (2019) Efficacy and safety of nitazoxanide in addition to standard of care for the treatment of severe acute respiratory illness. Clin Infect Dis 69(11):1903-1911

116. Kotch C, Barrett D, Teachey DT (2019) Tocilizumab for the treatment of chimeric antigen receptor T cell-induced cytokine release syndrome. Expert Rev Clin Immunol 15(8):813-822

117. Lee DW, Santomasso BD, Locke FL, Ghobadi A, Turtle CJ, Brudno JN, Maus MV, Park JH, Mead E, Pavletic S (2019) ASTCT consensus grading for cytokine release syndrome and neurologic toxicity associated with immune effector cells. Biol Blood Marrow Transpl 25(4):625-638

118. Park JH, Romero FA, Taur Y, Sadelain M, Brentjens RJ, Hohl TM, Seo SK (2018) Cytokine release syndrome grade as a predictive marker for infections in patients with relapsed or refractory B-cell acute lymphoblastic leukemia treated with chimeric antigen receptor T cells. Clin Infect Dis 67(4):533-540

119. Le RQ, Li L, Yuan W, Shord SS, Nie L, Habtemariam BA, Przepiorka D, Farrell AT, Pazdur R (2018) FDA approval summary: tocilizumab for treatment of chimeric antigen receptor T cell-induced severe or life-threatening cytokine release syndrome. Oncologist 23(8):943

120. Xu X, Han M, Li T, Sun W, Wang D, Fu B, Zhou Y, Zheng X, Yang Y, Li X (2020) Effective treatment of severe COVID-19 patients with tocilizumab. ChinaXiv 202003(00026):v1

121. Stockman LJ, Bellamy R, Garner P (2006) SARS: systematic review of treatment effects. PLoS Med 3(9):E343

122. Chen R-c, Tang X-p, Tan S-y, Liang B-1, Wan Z-y, Fang J-q, Zhong N (2006) Treatment of severe acute respiratory syndrome with glucosteroids: the Guangzhou experience. Chest 129(6):1441-1452

123. Lee N, Chan KA, Hui DS, Ng EK, Wu A, Chiu RW, Wong VW, Chan PK, Wong K, Wong E (2004) Effects of early corticosteroid treatment on plasma SARS-associated Coronavirus RNA concentrations in adult patients. J Clin Virol 31(4):304-309

124. Auyeung TW, Lee JS, Lai WK, Choi CH, Lee HK, Lee JS, Li PC, Lok KH, Ng YY, Wong WM (2005) The use of corticosteroid as treatment in SARS was associated with adverse outcomes: a retrospective cohort study. J Infect 51(2):98-102

125. Arabi YM, Mandourah Y, Al-Hameed F, Sindi AA, Almekhlafi GA, Hussein MA, Jose J, Pinto R, Al-Omari A, Kharaba A (2018) Corticosteroid therapy for critically ill patients with Middle East respiratory syndrome. Am J Respir Crit Care Med 197(6):757-767

126. Wu C, Chen X, Cai Y, Zhou X, Xu S, Huang H et al (2020) Risk factors associated with acute respiratory distress syndrome and death in patients with coronavirus disease 2019 pneumonia in Wuhan, China. JAMA Intern Med 180(7):1-11

127. Shang L, Zhao J, Hu Y, Du R, Cao B (2020) On the use of corticosteroids for 2019-nCoV pneumonia. Lancet 395(10225):683-684

128. Booth CM, Matukas LM, Tomlinson GA, Rachlis AR, Rose DB, Dwosh HA, Walmsley SL, Mazzulli T, Avendano M, Derkach P (2003) Clinical features and short-term outcomes of 144 patients with SARS in the greater Toronto area. JAMA 289(21):2801-2809

129. Lee N, Hui D, Wu A, Chan P, Cameron P, Joynt GM, Ahuja A, Yung MY, Leung C, To K (2003) A major outbreak of severe acute respiratory syndrome in Hong Kong. N Engl J Med 348(20):1986-1994
130. Tan EL, Ooi EE, Lin C-Y, Tan HC, Ling AE, Lim B, Stanton LW (2004) Inhibition of SARS coronavirus infection in vitro with clinically approved antiviral drugs. Emerg Infect Dis 10(4):581

131. Arabi YM, Shalhoub S, Mandourah Y, Al-Hameed F, Al-Omari A, Al Qasim E, Jose J, Alraddadi B, Almotairi A, Al Khatib K (2019) Ribavirin and interferon therapy for critically Ill patients with middle east respiratory syndrome: a multicenter observational study. Clin infect Dis 70(9):1837-1844

132. Nitric oxide investigated as COVID-19 Treatment. https://www. webmd.com/lung/news/20200409/nitric-oxide-investigated-ascovid19-treatment. Retrieved 10 Apr 2020

133. Casadevall A, Scharff MD (1995) Return to the past: the case for antibody-based therapies in infectious diseases. Clin Infect Dis 21(1):150-161

134. Casadevall A, Dadachova E, Pirofski A (2004) Passive antibody therapy for infectious diseases. Nat Rev Microbiol 2(9):695-703

135. Zhang JS, Chen JT, Liu YX, Zhang ZS, Gao H, Liu Y, Wang X, Ning Y, Liu YF, Gao Q (2005) A serological survey on neutralizing antibody titer of SARS convalescent sera. J Med Virol 77(2):147-150

136. Beigel JH, Voell J, Kumar P, Raviprakash K, Wu H, Jiao J-A, Sullivan E, Luke T, Davey RT Jr (2018) Safety and tolerability of a novel, polyclonal human anti-MERS coronavirus antibody produced from transchromosomic cattle: a phase 1 randomised, double-blind, single-dose-escalation study. Lancet Infect Dis 18(4):410-418

137. Robbins JB, Schneerson R, Szu SC (1995) Perspective: hypothesis: serum IgG antibody is sufficient to confer protection against infectious diseases by inactivating the inoculum. J Infect Dis 171(6): 1387-1398

138. Casadevall A, Pirofski A (2003) Antibody-mediated regulation of cellular immunity and the inflammatory response. Trends Immunol 24(9):474-478

139. Casadevall A, Scharff MD (1994) Serum therapy revisited: animal models of infection and development of passive antibody therapy. Antimicrob Agents Chemother 38(8):1695

140. Park WH (1932) Therapeutic use of antipoliomyelitis serum in preparalytic cases of poliomyelitis. J Am Med Assoc 99(13):1050-1053

141. Park WH, Freeman RG (1926) The prophylactic use of measles convalescent serum. J Am Med Assoc 87(8):556-558

142. Gallagher JR (1935) Use of convalescent measles serum to control measles in a preparatory school. Am J Public Health Nations Health 25(5):595-598

143. RAMBAR AC (1946) Mumps: use of convalescent serum in the treatment and prophylaxis of orchitis. Am J Dis Child 71(1):1-13

144. Luke TC, Casadevall A, Watowich SJ, Hoffman SL, Beigel JH, Burgess TH (2010) Hark back: passive immunotherapy for influenza and other serious infections. Crit Care Med 38:e66-e73

145. Luke TC, Kilbane EM, Jackson JL, Hoffman SL (2006) Meta-analysis: convalescent blood products for Spanish influenza pneumonia: a future H5N1 treatment? Ann Intern Med 145(8):599-609

146. Hung IF, To KK, Lee C-K, Lee K-L, Chan K, Yan W-W, Liu R, Watt C-L, Chan W-M, Lai K-Y (2011) Convalescent plasma treatment reduced mortality in patients with severe pandemic influenza A (H1N1) 2009 virus infection. Clin Infect Dis 52(4):447-456

147. Sahr F, Ansumana R, Massaquoi T, Idriss B, Sesay F, Lamin J, Baker S, Nicol S, Conton B, Johnson W (2017) Evaluation of convalescent whole blood for treating Ebola Virus Disease in Freetown, Sierra Leone. J Infect 74(3):302-309

148. Kraft CS, Hewlett AL, Koepsell S, Winkler AM, Kratochvil CJ, Larson L, Varkey JB, Mehta AK, Lyon GM III, FriedmanMoraco RJ (2015) The use of TKM-100802 and convalescent 
plasma in 2 patients with Ebola virus disease in the United States. Clin Infect Dis 61(4):496-502

149. Kong L, Zhou B (2006) Successful treatment of avian influenza with convalescent plasma. Hong Kong Med J 12(6):489

150. Zhou B, Zhong N, Guan Y (2007) Treatment with convalescent plasma for influenza A (H5N1) infection. N Engl J Med 357(14):1450-1451

151. Wu X-X, Gao H-N, Wu H-B, Peng X-M, Ou H-L, Li L-J (2015) Successful treatment of avian-origin influenza A (H7N9) infection using convalescent plasma. Int J Infect Dis 41:3-5

152. Cheng Y, Wong R, Soo Y, Wong W, Lee C, Ng M, Chan P, Wong $\mathrm{K}$, Leung C, Cheng G (2005) Use of convalescent plasma therapy in SARS patients in Hong Kong. Eur J Clin Microbiol Infect Dis 24(1):44-46

153. Yeh K-M, Chiueh T-S, Siu L, Lin J-C, Chan PK, Peng M-Y, Wan H-L, Chen J-H, Hu B-S, Perng C-L (2005) Experience of using convalescent plasma for severe acute respiratory syndrome among healthcare workers in a Taiwan hospital. J Antimicrob Chemother 56(5):919-922

154. Ko J-H, Seok H, Cho SY, Ha YE, Baek JY, Kim SH, Kim Y-J, Park JK, Chung CR, Kang E-S (2018) Challenges of convalescent plasma infusion therapy in Middle East respiratory coronavirus infection: a single centre experience. Antiviral Ther 23(7):617-622

155. Arabi YM, Hajeer AH, Luke T, Raviprakash K, Balkhy H, Johani S, Al-Dawood A, Al-Qahtani S, Al-Omari A, Al-Hameed F (2016) Feasibility of using convalescent plasma immunotherapy for MERS-CoV infection, Saudi Arabia. Emerg Infect Dis 22(9): 1554

156. Van Erp EA, Luytjes W, Ferwerda G, Van Kasteren PB (2019) Fc-mediated antibody effector functions during respiratory syncytial virus infection and disease. Front Immunol 10:548

157. Jenks JA, Goodwin ML, Permar SR (2019) The roles of host and viral antibody Fc receptors in herpes simplex virus (HSV) and human cytomegalovirus (HCMV) infections and immunity. Front Immunol 10:2110

158. Gunn BM, Yu W-H, Karim MM, Brannan JM, Herbert AS, Wec AZ, Halfmann PJ, Fusco ML, Schendel SL, Gangavarapu K (2018) A role for Fc function in therapeutic monoclonal antibody-mediated protection against Ebola virus. Cell Host Microbe 24(2):221-233 (e225)

159. China puts 245 COVID-19 patients on convalescent plasma therapy. https://www.xinhuanet.com/english/2020-02/28/c_13882 8177.htm. Retrieved 12 Apr 2020

160. Gajic O, Rana R, Winters JL, Yilmaz M, Mendez JL, Rickman OB, O’Byrne MM, Evenson LK, Malinchoc M, DeGoey SR (2007) Transfusion-related acute lung injury in the critically ill: prospective nested case-control study. Am J Respir Crit Care Med 176(9):886-891

161. Wan Y, Shang J, Sun S, Tai W, Chen J, Geng Q et al (2020) Molecular mechanism for antibody-dependent enhancement of coronavirus entry. J Virol 94(5):E02015

162. Mair-Jenkins J, Saavedra-Campos M, Baillie JK, Cleary P, Khaw F-M, Lim WS, Makki S, Rooney KD, Group CPS, Nguyen-VanTam JS (2015) The effectiveness of convalescent plasma and hyperimmune immunoglobulin for the treatment of severe acute respiratory infections of viral etiology: a systematic review and exploratory meta-analysis. J Infect Dis 211(1):80-90
163. Crowe JE, Firestone C-Y, Murphy BR (2001) Passively acquired antibodies suppress humoral but not cell-mediated immunity in mice immunized with live attenuated respiratory syncytial virus vaccines. J Immunol 167(7):3910-3918

164. Drugmaker Takeda is working on coronavirus drug. https://www. wsj.com/articles/drugmakertakeda-is-working-on-coronaviru sdrug-11583301660. Retrieved 10 Apr 2020

165. McGuire L, Redden W (1918) The use of convalescent human serum in influenza pneumonia-a preliminary report. Am J Public Health 8(10):741-744

166. Mo Y, Fisher D (2016) A review of treatment modalities for Middle East respiratory syndrome. J Antimicrob Chemother 71(12):3340-3350

167. Shen C, Wang Z, Zhao F, Yang Y, Li J, Yuan J et al (2020) Treatment of 5 critically ill patients with COVID-19 with convalescent plasma. JAMA 323(16):1582-1589

168. Anderson RM, Heesterbeek H, Klinkenberg D, Hollingsworth TD (2020) How will country-based mitigation measures influence the course of the COVID-19 epidemic? Lancet 395(10228):931-934

169. Liang B, Chen J, Li T, Wu H, Yang W, Li Y et al (2020) Clinical remission of a critically ill COVID-19 patient treated by human umbilical cord mesenchymal stem cells. Medicine 99(31):e21429

170. Leng Z, Zhu R, Hou W, Feng Y, Yang Y, Han Q, Shan G, Meng F, Du D, Wang S (2020) Transplantation of ACE2-mesenchymal stem cells improves the outcome of patients with COVID-19 pneumonia. Aging Dis 11(2):216-228

171. Foronjy RF, Dabo AJ, Cummins N, Geraghty P (2014) Leukemia inhibitory factor protects the lung during respiratory syncytial viral infection. BMC Immunol 15(1):41

172. Quinton LJ, Mizgerd JP, Hilliard KL, Jones MR, Kwon CY, Allen E (2012) Leukemia inhibitory factor signaling is required for lung protection during pneumonia. J Immunol 188(12):6300-6308

173. Metcalfe SM, Strom TB, Williams A, Fahmy TM (2015) Multiple sclerosis and the LIF/IL-6 axis: use of nanotechnology to harness the tolerogenic and reparative properties of LIF. Nanobiomedicine 2(Godište 2015):2-5

174. Mesoblast stem cell drugs for novel coronavirus. https://ipsce 11.com/2020/03/athersys-mesoblast-stem-cell-drugs-fornovelco ronavirus-covid-19/. Retrieved 31 Mar 2020

175. Ulich TR, Fann M-J, Patterson PH, Williams JH, Samal B, Del Castillo J, Yin S, Guo K, Remick DG (1994) Intratracheal injection of LPS and cytokines. V. LPS induces expression of LIF and LIF inhibits acute inflammation. Am J Physiol Lung Cell Mol Physiol 267(4):L442-L446

176. Wang J, Chen Q, Corne J, Zhu Z, Lee CG, Bhandari V, Homer RJ, Elias JA (2003) Pulmonary expression of leukemia inhibitory factor induces B cell hyperplasia and confers protection in hyperoxia. J Biol Chem 278(33):31226-31232

177. Metcalfe SM (2020) Mesenchymal stem cells and management of COVID-19 pneumonia. Med Drug Discov 5:100019

Publisher's Note Springer Nature remains neutral with regard to jurisdictional claims in published maps and institutional affiliations. 